\title{
Neuroprotective Potentials of Panax Ginseng Against Alzheimer's Disease: A Review of Preclinical and Clinical Evidences
}

\author{
Jing $\mathrm{Li}^{1 \dagger}$, Qingxia Huang ${ }^{1,2 \dagger}$, Jinjin Chen ${ }^{1}$, Hongyu $\mathrm{Qi}^{1}$, Jiaqi Liu ${ }^{1}$, Zhaoqiang Chen ${ }^{1}$, \\ Daqing Zhao ${ }^{1}$, Zeyu Wang ${ }^{3 *}$ and Xiangyan $\mathrm{Li}^{1 *}$
}

${ }^{1}$ Jilin Ginseng Academy, Key Laboratory of Active Substances and Biological Mechanisms of Ginseng Efficacy, Ministry of Education, Jilin Provincial Key Laboratory of Bio-Macromolecules of Chinese Medicine, Changchun University of Chinese Medicine, Changchun, China, ${ }^{2}$ Research Center of Traditional Chinese Medicine, College of Traditional Chinese Medicine, Changchun University of Chinese Medicine, Changchun, China, ${ }^{3}$ Department of Scientific Research, Changchun University of Chinese Medicine, Changchun, China

\section{OPEN ACCESS}

Edited by:

Muhammad Ayaz,

University of Malakand, Pakistan

Reviewed by:

Amjad Khan,

Gyeongsang National University,

South Korea

Cláudia Pereira,

University of Coimbra, Portugal

${ }^{*}$ Correspondence:

Zeyu Wang

zeyu781022@163.com

Xiangyan $\mathrm{Li}$

xiangyanli1981@163.com

${ }^{t}$ These authors have contributed

equally to this work

Specialty section: This article was submitted to

Ethnopharmacology,

a section of the journal

Frontiers in Pharmacology

Received: 30 March 2021

Accepted: 10 May 2021

Published: 02 June 2021

Citation:

Li J, Huang Q, Chen J, Qi H, Liu J, Chen Z, Zhao D, Wang $Z$ and $L i X$ (2021) Neuroprotective Potentials of Panax Ginseng Against Alzheimer's Disease: A Review of Preclinical and

Clinical Evidences.

Front. Pharmacol. 12:688490. doi: 10.3389/fphar.2021.688490
Alzheimer's disease (AD), a neurodegenerative disorder, is a major health concern in the increasingly aged population worldwide. Currently, no clinically effective drug can halt the progression of AD. Panax ginseng C.A. Mey. is a well-known medicinal plant that contains ginsenosides, gintonin, and other components and has neuroprotective effects against a series of pathological cascades in $A D$, including beta-amyloid formation, neuroinflammation, oxidative stress, and mitochondrial dysfunction. In this review, we summarize the effects and mechanisms of these major components and formulas containing $P$. ginseng in neuronal cells and animal models. Moreover, clinical findings regarding the prevention and treatment of $A D$ with $P$. ginseng or its formulas are discussed. This review can provide new insights into the possible use of ginseng in the prevention and treatment of $A D$.

Keywords: Alzeheimer's disease, ginseng (Panax ginseng C.A. Meyer), ginsenosidase, gintonin, neuroprotection

\section{INTRODUCTION}

Alzheimer's disease (AD) is a neurodegenerative disorder and is one of the most common causes of dementia in the elderly population (Jia et al., 2020). The global costs in 2030 due to dementia could be much higher than the predictions made by the World Alzheimer Report 2015, reaching \$2.54 trillion (Jia et al., 2018). According to the Alzheimer's Association, the incidence and prevalence, mortality and morbidity, use and costs of care, and the overall impact on the caregivers and society of AD are increasingly major concerns (Alzheimer's Association, 2020). The prevention and treatment of AD has become a global problem due to the increasingly aged population worldwide (Alzheimer's Association, 2020; Ikram et al., 2020). AD clinically manifests as apathy, anxiety, cognitive and functional decline, and the emergence of neuropsychiatric symptoms (Johansson et al., 2020; Cummings, 2021).

$\mathrm{AD}$ pathogenesis is defined by the extracellular deposition of beta-amyloid (A $\beta)$ and tau hyperphosphorylation (Vaz and Silvestre, 2020). A $\beta$ plaque formation is thought to be the main cause of AD symptoms, including memory deficit, due to its neurotoxic effect (Yankner et al., 1989; Sonawane et al., 2021). $A \beta$ is derived from $A \beta$ protein precursors (A $\beta P P s)$ through the amyloidogenic pathway (Hwang et al., 2012; Kwon et al., 2019). A $\beta$ accumulation accelerates tau 
phosphorylation (p-tau) during AD development (Gomes et al., 2019), whereas normal tau phosphorylation is essential for neuronal plasticity and axonal outgrowth (Arendt and Bullmann, 2013). Hyperphosphorylated tau protein is released from microtubules and self-assembles into neurotoxic insoluble aggregates such as intracellular neurofibrillary tangles (NFTs) (JeffKuret, 2008). The toxic effects of senile plaques composed of A $\beta$ peptides and NFTs on the brain cholinergic system, mitochondria, and axonal transport result in oxidative stress, intracellular $\mathrm{Ca}^{2+}$ overload, apoptosis, and glutamate dysregulation (Bader Lange et al., 2008; Aalinkeel et al., 2018). In addition, the senile plaques produce more $A \beta$ peptides through microglial activation and release of pro-inflammatory cytokines. The treatments for $\mathrm{AD}$ approved by the Food and Drug Administration are mainly based on reducing acetylcholine $(\mathrm{ACh})$ levels and glutamate excitotoxicity and inhibiting $\mathrm{A} \beta$ protein deposition in the brain; approved drugs include donepezil, rivastigmine hydrogen tartrate, galanthamine, and huperzine-A (Li et al., 2019; Kareti and P, 2020; Pardridge, 2020). Although these drugs can result in symptomatic improvement, they cannot reverse $\mathrm{AD}$ progression and cause various adverse effects after long-term use.

Panax ginseng C.A. Mey. (ginseng) is a well-known and valuable medicinal herb that has been widely used in China and other East Asian countries as traditional Chinese medicine and health food (Shi et al., 2019). Recent studies demonstrated that ginseng extracts, active components (ginsenosides and gintonin), and ginseng formulas can improve the symptoms of $\mathrm{AD}$ patients and inhibit the progression of $\mathrm{AD}$ by reducing the deposition of $\mathrm{A} \beta$ and tau protein hyperphosphorylation. These effects may be mediated by mitochondrial function, neuron conduction, apoptosis, calcium ions, and reactive oxygen species (ROS) (Rajabian et al., 2019; Guo et al., 2021). Ginsenosides, which are mainly classified into protopanaxadiol (PPD) and protopanaxatriol (PPT), according to their sapogenin, can result in significant improvement in $\mathrm{AD}$ symptoms (Im and Nah, 2013; Kim et al., 2018; Piao et al., 2020). Previous studies have confirmed that $\beta$-site APP cleaving enzyme 1 (BACE1, $\beta$-secretase) inhibitors can inhibit the formation of $A \beta$ (Karpagam et al., 2013), and acetylcholinesterase (AChE) inhibition can improve cognitive and memory function (Park et al., 2017). Molecular dynamics analysis combined with enzyme activity experiments showed that ginsenosides CK, F1, Rh1, and Rh2 are potential BACE1 inhibitors, inhibiting the formation of $\mathrm{A} \beta$ (Karpagam et al., 2013). In addition, ginsenosides F1, Rd, Rk3, 20(S)-Rg3, F2, and Rb2 possess strong AChE inhibitory activities, which can improve cognitive and memory function (Nah, 2012; Yang et al., 2019a). Gintonin, a component of ginseng, is a bioactive glycolipoprotein that forms nonsaponin multimers (Pyo et al., 2011; Nah, 2012; Jakaria et al., 2020; Choi et al., 2021). Recent studies have shown that gintonin can affect the activation of the phosphatidic acid receptor, which is involved in hemolysis, reducing the formation of $\mathrm{A} \beta$ and improving learning and memory abilities (Lee et al., 2018a; Kim et al., 2018). In addition, gintonin can also reduce the symptoms and progress of $\mathrm{AD}$ through neurogenesis, autophagy stimulation, anti-apoptosis effects, anti-oxidative stress, and antiinflammatory activities (Choi et al., 2021).

We first introduce the effects and mechanisms of ginsenosides, gintonin, and ginseng formulas in the prevention and treatment of $\mathrm{AD}$ based on the extensive in vitro and in vivo studies. Then, we summarize the clinical findings regarding the prevention and treatment of $\mathrm{AD}$ with ginseng or its formulas. This review can provide new insights into the possible use of ginseng in $\mathrm{AD}$ treatment.

\section{EFFECTS AND MECHANISMS OF GINSENG IN PREVENTING AND TREATING AD}

\section{Ginsenosides}

It has been reported that many ginsenosides can target the following pathological processes of $\mathrm{AD}$ : (1) inhibiting $\mathrm{A} \beta$ aggregation and tau hyperphosphorylation, (2) protecting against neuroinflammation and apoptosis, (3) increasing the secretion of neurotrophic factors, and (4) improving mitochondrial dysfunction.

\section{A $\beta$ Aggregation and Tau Hyperphosphorylation}

In $\mathrm{A} \beta_{1-40}$-induced $\mathrm{AD}$ rats, ginsenoside $\mathrm{Rb} 1$ can improve learning and memory by altering the amyloidogenic process of APP into a nonamyloidogenic process (Lin et al., 2019). Ginsenoside Rb1, an agonist of peroxisome proliferator-activated receptor- $\gamma \quad(\operatorname{PPAR} \gamma)$, could lower cholesterol levels and reduce the cytotoxicity induced by $\mathrm{A} \beta_{25-35}$ by decreasing lipid peroxidation and protecting the rigidity of the cytoskeleton and the membrane surface in PC12 cells (Changhong et al., 2021). Ginsenoside Rd increases soluble APP- $\alpha$ (sAPPa) levels and reduces extracellular A $\beta$ levels, enhancing cognitive and memory functions of ovariectomized rats (Yan et al., 2017). Ginsenoside Re inhibits the activity of BACE1 by increasing PPAR $\gamma$ expression at the mRNA and protein levels in N2a/APP695 cells and thereby reduces the generation of $A \beta_{1-40}$ and $A \beta_{1-42}$ (Cao et al., 2016). Another research showed that ginsenoside $\mathrm{Rg} 1$ can downregulate cyclindependent kinase 5 (CDK5) expression to inhibit the phosphorylation of PPAR $\gamma$ and the activity of its targets, $\mathrm{BACE}$ and insulin-degrading enzyme (IDE), reducing $\mathrm{A} \beta$ levels, and exerting neuroprotective effects against AD (Quan et al., 2020). In SweAPP-SK cells with mutant APP, Rg3 treatment significantly enhances neprilysin (NEP) gene expression, reducing the levels of $A \beta_{40}$ and $A \beta_{42}$ (Yang et al., 2009).

With respect to tau hyperphosphorylation, $\mathrm{Rd}$ pretreatment can maintain the functional balance between glycogen synthase kinase $3 \beta$ (GSK-3 $\beta$ ) and protein phosphatase 2A (PP-2A), inhibiting tau phosphorylation (Li et al., 2013). Moreover, Rd inhibits the hyperphosphorylation of tau protein at Ser199/202, Ser396, or Ser404, induced by okadaic acid microinfusion in rats and cortical neurons, increasing the PP-2A activity and protecting against $\mathrm{AD}$ ( $\mathrm{Li}$ et al., 2011). Collectively, these results suggest that ginsenosides $\mathrm{Rb} 1, \mathrm{Rd}, \mathrm{Re}$, and $\mathrm{Rg} 1$ can inhibit $A \beta$ aggregation to regulate the phosphorylation of tau protein in the prevention and treatment of $\mathrm{AD}$. 
TABLE 1 | Summary of effects and mechanisms of ginsenosides in neuronal cells and animal models.

\begin{tabular}{|c|c|c|c|c|c|c|}
\hline Ref & Ginsenosides & Model & Inducer & Experimental model & Mechanism & Effects \\
\hline $\begin{array}{l}\text { Zhao et al. } \\
(2014)\end{array}$ & Rg1 & $A D$ & $A \beta_{25-35}$ & $\begin{array}{l}\text { NG108-15 neuroglial } \\
\text { cells }\end{array}$ & $\begin{array}{l}\text { TLR3, TLR4, NF- } k B \text {, TRAF-6, TNF- } \\
\alpha, \text { IFN- } \beta \text {, iNOS } \downarrow\end{array}$ & Neuroinflammation \\
\hline Li et al. (2019) & Rg1 & $A D$ & & $3 \times \mathrm{Tg}-\mathrm{AD}$ mice & $\begin{array}{l}\text { Arachidonic acid, 11b-PGF2a, cytc } \\
\text { p450, enzyme prostaglandin-F } \\
\text { synthase, tryptophan, Iysine } \downarrow\end{array}$ & $\begin{array}{l}\text { Oxidative stress, inflammation } \\
\text { reaction }\end{array}$ \\
\hline $\begin{array}{l}\text { Yang et al. } \\
(2020)\end{array}$ & Rg1 & $A D$ & & SAMP8 mice & $\begin{array}{l}\text { Activated microglia cells, activated } \\
\text { astrocytes, iNOS, } A \beta \downarrow\end{array}$ & $\begin{array}{l}\text { Oxidative stress, } \\
\text { neuroinflammation }\end{array}$ \\
\hline $\begin{array}{l}\text { Xu et al. } \\
(2019)\end{array}$ & Rg1 & $\begin{array}{l}\text { Neuronal } \\
\text { damage }\end{array}$ & $\mathrm{H}_{2} \mathrm{O}_{2}$ & $\begin{array}{l}\text { Hippocampal neurons } \\
\text { cells }\end{array}$ & $\begin{array}{l}\beta \text {-Galactosidase, ROS, caspase-3, } \\
\text { NOX2, p22phox, NLRP1, ASC, } \\
\text { caspase-1, IL-1 } \beta, I L-18 \downarrow\end{array}$ & $\begin{array}{l}\text { Oxidative stress, apoptosis, } \\
\text { neuroinflammation }\end{array}$ \\
\hline $\begin{array}{l}\text { Quan et al. } \\
\text { (2020) }\end{array}$ & $\operatorname{Rg} 1$ & $A D$ & $A \beta_{1-42}$ & $\begin{array}{l}\text { Rat hippocampal } \\
\text { neurons cells }\end{array}$ & $\begin{array}{l}\text { p-PPAR } \gamma, \text { CDK5, BACE1, APP, } \\
\text { A } \beta 1-42 \downarrow \\
\text { IDE } \uparrow\end{array}$ & $\begin{array}{l}\text { Apoptosis, } A \beta \text { degradation and } \\
\text { reduction }\end{array}$ \\
\hline $\begin{array}{l}\text { Nie et al. } \\
(2017)\end{array}$ & $\operatorname{Rg} 1$ & $A D$ & & $3 \times$ Tg-AD mice & SYN2, CPLX2, SNP25, PSD-95个 & $\begin{array}{l}\text { Modulating the expression of the } \\
\text { proteins of memory and } \\
\text { depression }\end{array}$ \\
\hline $\begin{array}{l}\text { Cui et al. } \\
(2020)\end{array}$ & $\operatorname{Rg} 2$ & $A D$ & $A \beta_{25-35}$ & Male SD rats & $\begin{array}{l}\text { Caspase-3, Bax } \downarrow \\
\text { Bcl-2, p-Akt } \uparrow\end{array}$ & Apoptosis \\
\hline $\begin{array}{l}\text { Cui et al. } \\
\text { (2017) }\end{array}$ & $\operatorname{Rg} 2$ & & $A \beta_{25-35}$ & PC12 cells & 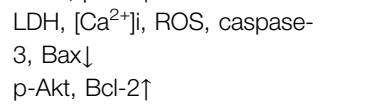 & $\begin{array}{l}\text { Mitochondrial dysfunction, } \\
\text { apoptosis }\end{array}$ \\
\hline Li et al. (2007) & $\operatorname{Rg} 2$ & & Glutamate & PC12 cells & 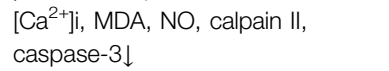 & Anti-oxidation, anti-apoptosis \\
\hline $\begin{array}{l}\text { Joo et al. } \\
(2008)\end{array}$ & Rg3 & $A D$ & $\mathrm{~A} \beta_{42}$ & BV-2 microglial cells & TNF $\alpha, I L-1 \beta$, iNOS $\downarrow$ & $\begin{array}{l}\text { Neurotoxicity, microglial } \\
\text { activation, inflammation }\end{array}$ \\
\hline $\begin{array}{l}\text { Lee et al. } \\
\text { (2013) }\end{array}$ & Rg3 & $\begin{array}{l}\text { AD/learning and } \\
\text { memory } \\
\text { impairments }\end{array}$ & $\begin{array}{l}\text { D-Galactose/ } \\
\text { LPS }\end{array}$ & Adult male SD rats & $\begin{array}{l}\text { Caspase-3, caspase-9, Bax, AlF, } \\
\text { cyto C, Bcl-2, TNF- } \alpha, I L-1 \beta \text {, } \\
\text { COX- } 2 \downarrow\end{array}$ & $\begin{array}{l}\text { Mitochondrial dysfunction, } \\
\text { energy metabolism, ETC, amino } \\
\text { acid metabolism, purine } \\
\text { metabolism, anti-apoptosis, } \\
\text { neuroinflammation }\end{array}$ \\
\hline $\begin{array}{l}\text { Aalinkeel et al. } \\
\text { (2018) }\end{array}$ & $\begin{array}{l}\text { PLGA- } \\
\text { Rg3 NPs }\end{array}$ & $A D$ & $A \beta_{1-42}$ & C6/THP-1 cells & Cyto C, ROS, TNF- $\alpha, I L-1 \beta \downarrow$ & $\begin{array}{l}\text { A } \beta \text { plaques, } A \beta P P-A 4 \text {, oxidative } \\
\text { stress, mitochondrial dysfunction, } \\
\text { neuroinflammation }\end{array}$ \\
\hline $\begin{array}{l}\text { Lin et al. } \\
\text { (2019) }\end{array}$ & $\mathrm{Rb} 1$ & $A D$ & $A \beta_{1-40}$ & Male Wistar rats & $\| \mathrm{L}-1 \beta, A \beta, \mathrm{GFAP} \downarrow$ & $A \beta$ plaques, neuroinflammation \\
\hline $\begin{array}{l}\text { Wang et al. } \\
(2018)\end{array}$ & $\mathrm{Rb} 1$ & $A D$ & $A \beta_{1-40}$ & Male SD rats & 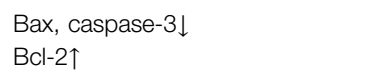 & Apoptosis \\
\hline $\begin{array}{l}\text { Changhong } \\
\text { et al. (2021) }\end{array}$ & $\mathrm{Rb} 1$ & $A D$ & $A \beta_{25-35}$ & PC12 cells & $\begin{array}{l}\text { Cholesterol, ROS, lipid } \\
\text { peroxidation } \downarrow \\
\text { PPAR } \gamma \uparrow\end{array}$ & $\begin{array}{l}\text { Apoptosis, PPAR } \gamma \text { activation, } \\
\text { cholesterol reduction }\end{array}$ \\
\hline $\begin{array}{l}\text { Zhao et al. } \\
\text { (2018) }\end{array}$ & $\mathrm{Rb} 1$ & $A D$ & $A \beta_{1-40}$ & Male SD rats & Nestin, GFAP, NSE, NSCs, NPCs $\uparrow$ & $\begin{array}{l}\text { Promote the proliferation and } \\
\text { differentiation of endogenous } \\
\text { NSCs }\end{array}$ \\
\hline $\begin{array}{l}\text { Yang et al. } \\
(2020)\end{array}$ & $\mathrm{Rg} 3$ + Rb1 & $A D$ & & SAMP8 mice & $\begin{array}{l}\text { TNF- } \alpha \text {, activated microglia cells, } \\
\text { activated astrocytes, ASC, } \\
\text { caspase- } 1 \text {, iNOS, } A \beta \downarrow\end{array}$ & $\begin{array}{l}\text { Oxidative stress, } \\
\text { neuroinflammation }\end{array}$ \\
\hline $\begin{array}{l}\text { Han et al. } \\
(2019)\end{array}$ & $\mathrm{F} 1$ & $A D$ & & Old APP/PS1 mice & $\begin{array}{l}\mathrm{A} \beta \text { plaque } \downarrow \\
\mathrm{pCREB}, \mathrm{BDNF} \uparrow\end{array}$ & $\begin{array}{l}\text { Amyloid protein }(A \beta) \\
\text { accumulation }\end{array}$ \\
\hline $\begin{array}{l}\text { Du et al. } \\
(2018)\end{array}$ & $\mathrm{Rf}$ & $A D$ & $A \beta_{42}$ & N2A cells & $\begin{array}{l}\mathrm{ROS}, \mathrm{Ca}^{2+}, \mathrm{IFN}-\gamma \downarrow \\
\mathrm{Mmp}, \mathrm{IL}-13 \uparrow\end{array}$ & $\begin{array}{l}\text { Apoptosis, neuroinflammation, } \\
\text { oxidative stress }\end{array}$ \\
\hline $\begin{array}{l}\text { Yang et al. } \\
(2019 b)\end{array}$ & CK & $\begin{array}{l}\text { Memory } \\
\text { impaired }\end{array}$ & $\begin{array}{l}\text { Scopolamine } \\
\text { hydrobromide }\end{array}$ & ICR mice & 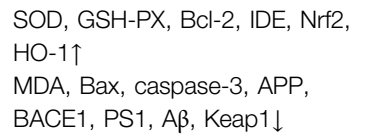 & $\begin{array}{l}\text { A } \beta \text { plaques, neurotoxicity, } \\
\text { oxidative stress, apoptosis }\end{array}$ \\
\hline $\begin{array}{l}\text { Chen et al. } \\
\text { (2019) }\end{array}$ & CK & $A D$ & $\mathrm{~A} \beta_{1-42}$ & HT22 cells & 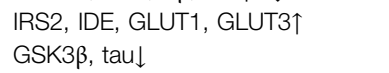 & $\begin{array}{l}\text { A } \beta \text { intake and accumulation, } \\
\text { energy metabolism disorder }\end{array}$ \\
\hline $\begin{array}{l}\text { Park et al. } \\
(2012)\end{array}$ & $\mathrm{CK}$ & Inflammation & LPS & $\begin{array}{l}\text { Male C57BL/6 mice/ } \\
\text { BV2 microglial cells/ } \\
\text { primary cultured } \\
\text { microglia }\end{array}$ & $\begin{array}{l}\text { Number of activated microglia, NO, } \\
\text { TNF- } \alpha, I L-1 \beta \text {, iNOS, IL-6, MCP-1, } \\
\text { MMP-3, MMP-9, ROS, NADPH, } \\
\text { MAPKS } \downarrow \\
\text { CREB } \uparrow\end{array}$ & $\begin{array}{l}\text { Microglial activation, NF-кB/ap-1 } \\
\text { activities suppresses } \\
\text { inflammatory molecules }\end{array}$ \\
\hline
\end{tabular}


TABLE 1 | (Continued) Summary of effects and mechanisms of ginsenosides in neuronal cells and animal models.

\begin{tabular}{|c|c|c|c|c|c|c|}
\hline Ref & Ginsenosides & Model & Inducer & Experimental model & Mechanism & Effects \\
\hline $\begin{array}{l}\text { Liu et al. } \\
\text { (2019) }\end{array}$ & $\mathrm{Re}$ & $A D$ & $A \beta_{25-35}$ & SH-SY5Y cells & $\begin{array}{l}\text { Caspase-3/7, caspase-9, cyt C, } \\
\text { ASK-1, JNK, Bax, ROS } \downarrow \\
\text { Caspase-8, caspase-12 } \rightarrow \\
\text { MMP, ATP, Bcl-2/Bax, GSH, } \\
\text { SOD, Gpx } \uparrow\end{array}$ & $\begin{array}{l}\text { Mitochondrial apoptosis, } \\
\text { oxidative damage, oxidative } \\
\text { stress }\end{array}$ \\
\hline $\begin{array}{l}\text { Cao et al. } \\
(2016)\end{array}$ & $\mathrm{Re}$ & $A D$ & & N2A/APP695 cells & $\begin{array}{l}\text { SAPP } \beta, \text { C99, BACE } 1 \downarrow \\
\text { PPAR } \gamma \text { protein and mRNA } \uparrow\end{array}$ & $A \beta$ production \\
\hline Li et al. (2018) & $\mathrm{Re}$ & $A D$ & $A \beta_{25-35}$ & Male kunming mice & $\begin{array}{l}\text { Tryptophan } \downarrow \\
\text { LPC, hexadecasphinganine, } \\
\text { phytosphingosine, phenylalanine } \uparrow\end{array}$ & Metabolomics \\
\hline $\begin{array}{l}\text { Liu et al. } \\
\text { (2012) }\end{array}$ & $\mathrm{Rd}$ & $A D$ & $\mathrm{~A} \beta_{1-40}$ & Male SD rats & 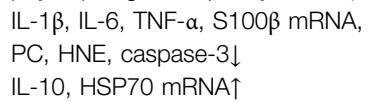 & $\begin{array}{l}\text { Inflammation, oxidative stress, } \\
\text { apoptosis }\end{array}$ \\
\hline $\begin{array}{l}\text { Liu et al. } \\
\text { (2015a) }\end{array}$ & $\mathrm{Rd}$ & $A D$ & & APP transgenic mice & $\begin{array}{l}\mathrm{IL}-1 \beta, \mathrm{IL}-6, \mathrm{TNF}-\alpha, \mathrm{S} 100 \beta \text { mRNA, } \\
\mathrm{NF}-\kappa \mathrm{B} \text { p } 65 \downarrow \\
\mathrm{IL}-10 \uparrow\end{array}$ & Inflammation, NF-кB \\
\hline Li et al. (2013) & $\mathrm{Rd}$ & $A D$ & & APP transgenic mice & $\begin{array}{l}\text { GSK-3 } \beta, \text { Tyr216 } \\
\text { Ser9, PP-2A } \uparrow\end{array}$ & p-tau \\
\hline $\begin{array}{l}\text { Liu et al. } \\
\text { (2015b) }\end{array}$ & $\mathrm{Rd}$ & $A D$ & $A \beta_{25-35}$ & $\begin{array}{l}\text { Primary cultured } \\
\text { hippocampal neurons } \\
\text { cells }\end{array}$ & $\begin{array}{l}\text { ROS, Bax mRNA, caspase-3, cyto } \\
\text { C mRNA } \downarrow \\
\text { SOD, GSH-Px, Bcl- } 2 \text { mRNA } \uparrow\end{array}$ & $\begin{array}{l}\text { Oxidative stress, neuronal } \\
\text { apoptosis }\end{array}$ \\
\hline Li et al. (2011) & $\mathrm{Rd}$ & $A D$ & Okadaic acid & $\begin{array}{l}\text { Adult male SD rats/ } \\
\text { Cortical neurons cells }\end{array}$ & $\begin{array}{l}\mathrm{Tau} \downarrow \\
\mathrm{P}-2 \mathrm{~A} \uparrow\end{array}$ & Tau \\
\hline $\begin{array}{l}\text { Yan et al. } \\
(2017)\end{array}$ & $\mathrm{Rd}$ & $A D$ & $\begin{array}{l}\text { Ovariectomy/ } \\
\text { Inhibitor }\end{array}$ & $\begin{array}{l}\text { Adult female rats/ } \\
\text { HT22 hippocampal } \\
\text { neuronal cells }\end{array}$ & $\begin{array}{l}\text { BACE1, A } \$ \downarrow \\
\text { SAPP } \alpha, \text { ADAM } \uparrow\end{array}$ & Activating estrogen-like activity \\
\hline $\begin{array}{l}\text { Kim et al. } \\
(2014)\end{array}$ & $\mathrm{Re}+\mathrm{rd}$ & & & Neuro2a cells & $\begin{array}{l}\text { ChAT, VAChT, ach, MAP-2, p75, } \\
\text { p21, TrkA } \uparrow\end{array}$ & Cholinergic markers \\
\hline
\end{tabular}

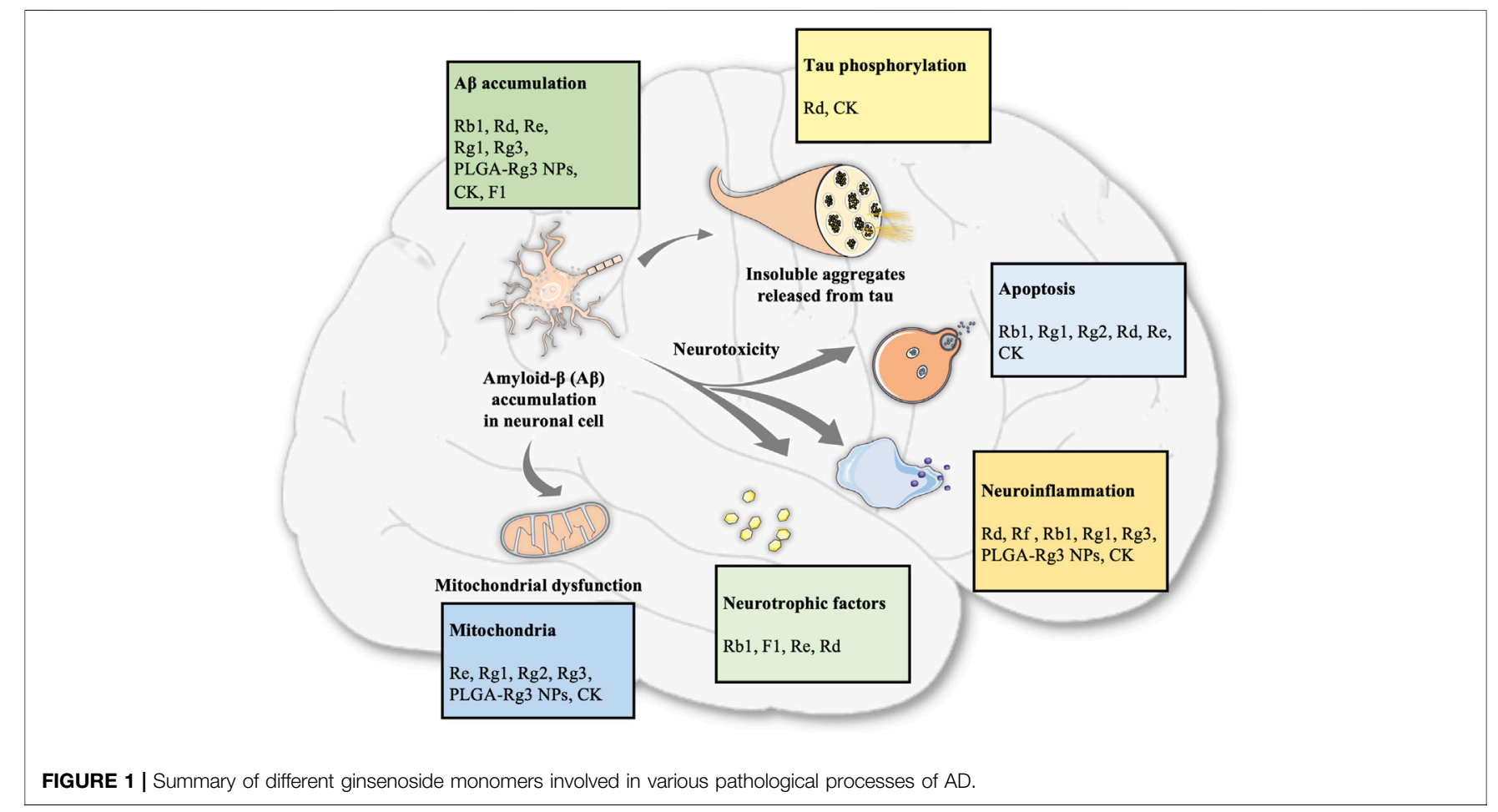




\section{Neuroinflammation}

Neuroinflammation is a continuous process that is implicated in the preclinical, moderate, and late stages of $\mathrm{AD}$ (Sung et al., 2020). In APP transgenic mice, Rd pretreatment at $10 \mathrm{mg} / \mathrm{kg}$ significantly suppresses the NF- $\mathrm{KB}$ pathway activity, reducing the generation of pro-inflammatory cytokines, such as interleukin-1 beta (IL-1 $\beta$ ), IL-6, tumor necrosis factor- $\alpha$ (TNF$\alpha$ ), and S100 calcium-binding protein B (S100ß), which can improve learning and memory abilities (Liu et al., 2015a). Meanwhile, Rd exerts obvious anti-inflammatory, antioxidative, and anti-apoptotic effects by reducing caspase- 3 expression and apoptosis of normal cells in $\mathrm{A} \beta_{1-40}$-induced AD model rats (Liu et al., 2012). Ginsenoside Rf significantly alleviates $A \beta$-induced neuronal death in N2A cells and memory deficits in $A \beta$-treated mice by alleviating inflammation and enhancing $A \beta$ degradation, which suggests that Rf decreases $\mathrm{A} \beta$-induced neurotoxicity during $\mathrm{AD}$ development (Du et al., 2018). Ginsenoside Rg1 can reduce the NADPH oxidase 2 (NOX2)-mediated ROS production and neuronal apoptosis, which in turn inhibits the nucleotide-binding domain and leucine-rich repeat pyrin domain-containing protein 1 (NLRP1) inflammasome in $\mathrm{H}_{2} \mathrm{O}_{2}$-induced hippocampal neurons (Xu et al., 2019). Moreover, the combination of Rb1 with Rg1 can reduce brain $A \beta$ production by regulating multiple processes, including NLRP3 inflammasome, TNF- $\alpha$ levels, oxidative stress, and astrocyte and microglia activation (Yang et al., 2020). Rb1 has a stronger effect on reducing the levels of apoptosis-related proteins in the hippocampus, and $\mathrm{Rg} 1$ has a stronger effect in decreasing iNOS levels and activating glial cells (Yang et al., 2020). In addition, ginsenoside Rg1 suppresses the TLR3/4 signaling pathway to decrease inflammatory factors in $\mathrm{A} \beta_{25-35}$-induced NG108-15 cells (Zhao et al., 2014). In lipopolysaccharide (LPS)-induced rats, Rg3 administration significantly alleviates cognitive impairment by inhibiting the expression of pro-inflammatory mediators (TNF- $\alpha$, IL-1 $\beta$, and cyclooxygenase 2 [COX-2]) in the brain (Lee et al., 2013). In $\mathrm{A} \beta_{42}$-treated BV-2 cells, the binding of NF- $\mathrm{KB}$ p65 to its DNA consensus sequences and TNF- $\alpha$ expression in activated microglia are effectively reduced by $\mathrm{Rg} 3$ treatment (Joo et al., 2008). Compound K (CK), a metabolite biotransformed from ginsenosides $\mathrm{Rb} 1, \mathrm{Rb} 2$, and $\mathrm{Rc}$ (Oh and Kim, 2016), can suppress various inflammatory molecules in LPS-stimulated BV2 cells and primary microglia by regulating the mitogen-activated protein kinase (MAPKs), NF- $\mathrm{kB} / \mathrm{AP}-1$, and HO-1/ARE signaling pathways (Park et al., 2012). These in vitro and in vivo findings indicate that major ginsenosides can alleviate inflammation in hippocampal neurons and microglia by mainly regulating the NF- $\mathrm{KB}$ pathway and NLRP3 inflammasome.

\section{Neurotrophic Factors}

Neurotrophic factors are endogenous proteins that maintain survival and differentiated functions of neurons, including the brain-derived neurotrophic factor (BDNF) and tropomyosinrelated kinases (Trks) A, B, and C (Schindowski et al., 2008). A study showed that $\mathrm{Rb} 1$ can promote endogenous neural stem cell proliferation and differentiation by increasing the protein levels of Nestin, glial fibrillary acidic protein (GFAP), and nucleotide sugar epimerase (NSE), thereby improving cognitive function of $\mathrm{AD}$ rats (Zhao et al., 2018). Ginsenoside F1 can decrease phosphorylated cAMP-response element binding protein (CREB) and increase cortical BDNF levels in the hippocampus, reducing $A \beta$ plaques and improving memory function of APP/PS1 double-transgenic AD mice (Han et al., 2019). With respect to other neurotrophic factors, the gene and protein expression levels of the nerve growth factor receptor p75 and TrkA in Neuro2a cells are increased by ginsenoside Re and Rd, which suggest that the NGF-TrkA signaling pathway mediates the ginsenoside-induced neuroprotective effects against AD progression (Kim et al., 2014).

\section{Apoptosis}

The balance between of pro-apoptotic and anti-apoptotic factors in brain tissue plays important roles in improving cognitive and memory functions in $\mathrm{AD}$. Rb1 administration significantly reduces the levels of Bax and cleaved caspase- 3 and enhances Bcl-2 levels in the hippocampus to prevent cognitive deficit of $A \beta_{1-40}$-induced rats (Wang et al., 2018; Lin et al., 2019). In $\mathrm{A} \beta_{25-35}$-induced PC12 cells and hippocampal CA1 neurons, Rg2 improves cell survival and inhibits apoptosis by promoting the $\mathrm{Bcl}-2 /$ Bax ratio and attenuating the cleavage of caspase- 3 , which is mediated by the enhancement of PI3K/Akt signaling (Cui et al., 2017; Cui et al., 2020). Meanwhile, $A \beta_{25-35}$-induced oxidative stress and neuronal apoptosis are, obviously, ameliorated by Rd by keeping the oxidation-anti-oxidation balance and regulating apoptotic proteins, such as Bax, Bcl-2, and cytochrome c (Cyto C) (Liu et al., 2015b). In A $\beta$-induced SH-SY5Y cells, Re can elevate the ratio of $\mathrm{Bcl}-2 / \mathrm{Bax}$ and reduce the release of Cyto $\mathrm{C}$ to maintain mitochondrial function by regulating the apoptosis signal-regulating kinase 1 (ASK1)/JNK/Bax and Nrf2/HO-1 pathways (Liu et al., 2019). Ginsenoside Rg2 significantly attenuates glutamate-induced neurotoxic effects through mechanisms related to anti-oxidative (malondialdehyde [MDA] and nitrogen oxide [NO]) and antiapoptotic (caspase-3) mechanisms (Li et al., 2007). In a scopolamine-exposed $\mathrm{AD}$ mouse model, $\mathrm{CK}$ was found to enhance Nrf2/Keap1 signaling, increasing the anti-oxidative activity and reducing neuronal apoptosis, which can regulate the balance between $A \beta$ production and clearance and improve memory function (Yang et al., 2019b). Taken together, ginsenosides Rb1, Rg2, $\mathrm{Re}$, and $\mathrm{Rd}$ can regulate apoptosis-related proteins, including Bcl-2, $B a x$, and Cyto $C$, reducing $A \beta$-induced or tau protein-induced neurotoxicity during $\mathrm{AD}$ development.

\section{Mitochondrial Dysfunction}

Mitochondrial dysfunction, including mtDNA lesions and reduced electron transport chain (ETC) enzyme function, is found in the brains of $\mathrm{AD}$ subjects, highlighting potential treatment strategies for AD (Perez Ortiz and Swerdlow, 2019). Metabolomic analysis showed that Re treatment can restore metabolic profiling including lecithin, amino acids, and sphingolipids, to exert protective effects in $\mathrm{AD}$ mice ( $\mathrm{Li}$ et al., 2018). Rg1 can improve memory impairment and depression-like behavior in $3 \times \mathrm{Tg}-\mathrm{AD}$ mice by upregulating the expression of the depression and memory-related proteins complexin-2 (CPLX2), 
TABLE 2 | Summary of effects and mechanisms of extracts or fractions from ginseng in neuronal cells and animal models.

\begin{tabular}{|c|c|c|c|c|c|c|}
\hline Ref & Extract/fraction & Model & Inducer & Experimental model & Mechanisms & Effects \\
\hline $\begin{array}{l}\text { Lee et al. } \\
(2017)\end{array}$ & Red ginseng oil & $A D$ & $A \beta_{25-35}$ & PC12 cells & $\begin{array}{l}\mathrm{Ca}^{2+}, \text { Bax, caspase-3, caspase-9, } \\
\text { PARP-1, JNK, p38 NF-kB, iNOS, COX- } \\
2 \text {, PGE2, NO, TNF- } \alpha \downarrow \\
\text { MMP, Bcl-2 } \uparrow\end{array}$ & $\begin{array}{l}\text { Mitochondrial dysfunction, apoptosis, } \\
\text { neuroinflammation }\end{array}$ \\
\hline $\begin{array}{l}\text { Lee et al. } \\
\text { (2018b) }\end{array}$ & Red ginseng oil & $A D$ & $A \beta_{25-35}$ & PC12 cells & 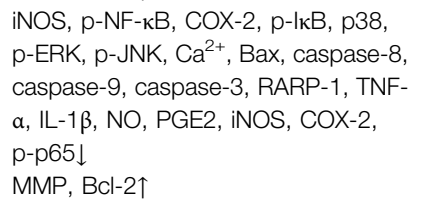 & $\begin{array}{l}\text { Oxidative stress, apoptotic responses, } \\
\text { pro-inflammatory mediators }\end{array}$ \\
\hline $\begin{array}{l}\text { Shin et al. } \\
\text { (2021) }\end{array}$ & $\begin{array}{l}\text { Nonsaponin fraction with } \\
\text { rich polysaccharide (NFP) } \\
\text { from red ginseng }\end{array}$ & $A D$ & $\mathrm{~A} \beta_{1-42}$ & $\begin{array}{l}14 \text { months old SD } \\
\text { rats } / 5 \times \text { FAD mice/ } \\
\text { HT2 } 2 \text { cells }\end{array}$ & $\begin{array}{l}\text { Iba- } 1(+) \text { area } \downarrow \\
\text { NeuN-positive cells, mitochondrial } \\
\text { numbers, mitochondrial dynamics, } \\
\text { OCR, ATP, mitochondrial respiration } \uparrow \\
\text { Defective brain mitochondrial } \\
\text { dynamics, number of DCX (+) neurons, } \\
\text { dendritic morphology }\end{array}$ & $\begin{array}{l}\text { A } \beta \text { deposition, neuroinflammation, } \\
\text { neurodegeneration, mitochondrial } \\
\text { dysfunction, impaired adult } \\
\text { neurogenesis, cognitive dysfunction }\end{array}$ \\
\hline $\begin{array}{l}\text { Shin et al. } \\
\text { (2019) }\end{array}$ & KRG extracts & $A D$ & $\mathrm{~A} \beta_{1-42}$ & $\begin{array}{l}5 \times \text { FAD mice/HT22 } \\
\text { cells }\end{array}$ & $\begin{array}{l}\text { 4G8 }(+) \text { arealba- } 1(+), \text { GFAP }(+), \text { Ki-67 } \\
(+), D C X(+) \downarrow \\
\text { Nonmitochondrial respiration } \downarrow \\
\text { OCR, basal respiration, ATP-linked } \\
\text { respiration Maximal respiration } \\
\text { capacity } \uparrow\end{array}$ & $\begin{array}{l}\text { A } \beta \text { accumulation, neuroinflammation, } \\
\text { impaired adult neurogenesis, neuronal } \\
\text { death, cognitive dysfunction, } \\
\text { mitochondrial dysfunction }\end{array}$ \\
\hline
\end{tabular}

synapsin-2 (SYN2), and synaptosomal-associated protein 25 (SNP25) (Nie et al., 2017). In AD rats, Rg3 can prevent cognitive impairment by directly or indirectly improving mitochondrial dysfunction, ETC function, and amino acid/ purine metabolism (Zhang et al., 2019). In A $\beta$-induced HT22 cells, CK treatment can regulate abnormal expression of proteins related to energy metabolism, promoting $A \beta$ degradation and inhibiting tau expression (Chen et al., 2019).

Overall, the neuroprotective effects of ginsenosides against $\mathrm{AD}$ are mediated by the regulation of $\mathrm{A} \beta$ accumulation, inflammation, apoptosis, neurotrophic factors, and mitochondrial function, as shown in Table $\mathbf{1}$ and Figure $\mathbf{1}$.

\section{Gintonin}

The role of gintonin in the prevention and treatment of $\mathrm{AD}$ has been evaluated for many years. Gintonin exerts anti-AD effects by affecting $\mathrm{A} \beta$ plaque deposition, $\mathrm{sA} \beta \mathrm{PP} \alpha$ release, the cholinergic system, neurotrophic factors, autophagy and apoptosis, and $G$ protein-coupled lysophosphatidic acid (LPA) receptors. Gintonin administration attenuates $\mathrm{A} \beta$ plaque deposition and stimulates $\mathrm{sA} \beta \mathrm{PPa}$ release, improving memory impairment in mice with $\mathrm{AD}$, suggesting that gintonin results in the formation of the beneficial sA $\beta \mathrm{PP} \alpha$ rather than neurotoxic $\mathrm{A} \beta$ (Hwang et al., 2012). With respect to the cholinergic system, gintonin can increase choline acetyltransferase expression, causing the release of $\mathrm{ACh}$ and attenuating $\mathrm{A} \beta$-induced cholinergic impairments in a transgenic AD mouse model (Kim et al., 2015a). The release and expression of the vascular endothelial growth factor (VEGF) in cortical astrocytes are stimulated by gintonin, which may be mediated by the LPA1/3 receptor or other receptors, exerting neuroprotective effects against hypoxia insults (Kim et al., 2016; Choi et al., 2019). Moreover, gintonin can induce autophagic flux in astrocytes via activation of the AMPKmTOR signaling pathway and efficiently suppress the production of NO by regulating MAPK and NF- $\kappa \mathrm{B}$ pathways (Saba et al., 2015; Rahman et al., 2020). Importantly, gintonin, an LPA receptor ligand, can interact with LPA receptors, which are abundantly expressed in astrocytes to induce transient increases in intracellular $\mathrm{Ca}^{2+}$ concentrations $\left(\left[\mathrm{Ca}^{2+}\right] \mathrm{i}\right)$, affecting neurotransmitter release and synaptic transmission and subsequently enhancing cognition. However, ginsenosides or other active components in ginseng have no effect on $\left[\mathrm{Ca}^{2+}\right] \mathrm{i}$, which may be related to the chemical characteristics of gintonin and its action on G protein-coupled receptors (Im and Nah, 2013; Kim et al., 2015b; Choi et al., 2015).

\section{Other Extracts or Fractions of Ginseng}

Apart from ginsenosides and gintonin, extracts or fractions from ginseng have also been widely investigated to explore their molecular mechanisms against $\mathrm{AD}$ in a series of cell and animal models. Ginseng extracts result in a reduction of $\mathrm{A} \beta$ amount, which may be related to multiple targets, including the balance between mitochondrial fusion and fission, basal respiration, and neuroinflammation attenuation in the $\mathrm{AD}$ brain (Chen et al., 2006; Shin et al., 2019). The Korean red ginseng extract, which may regulate alternative pathways such as mitochondrial dysfunction and $\mathrm{A} \beta$ degradation/clearance, inhibits tau aggregation but has no direct effect on $A \beta_{1-42}$ accumulation (Shin et al., 2020). The oil from red ginseng, containing linoleic acid, $\beta$-sitosterol, and stigmasterol, exhibits protective effects against $A \beta_{25-35}$-induced damage through inhibition of the NF- $\kappa \mathrm{B}$ and MAPK pathway-mediated inflammation and apoptosis (Lee et al., 2018b). Red ginseng oil can also downregulate the $\mathrm{p} 38 /-\mathrm{JNK} /-\mathrm{NF}-\kappa \mathrm{B}$ pathway to 
TABLE 3 | Summary of effects and mechanisms of formulas containing ginseng in neuronal cells and animal models.

\begin{tabular}{|c|c|c|c|c|c|c|c|}
\hline Ref & Formulas & Medicines & Model & Inducer & $\begin{array}{l}\text { Experimental } \\
\text { model }\end{array}$ & Mechanism & Effects \\
\hline $\begin{array}{l}\text { Yang } \\
\text { et al. } \\
(2017)\end{array}$ & $\begin{array}{l}\text { Fuzheng } \\
\text { Quxie } \\
\text { Decoction }\end{array}$ & $\begin{array}{l}\text { Renshen, huan glian, and } \\
\text { chuanxiong }(9: 6: 5)\end{array}$ & $A D$ & & SAMP8 mice & $\begin{array}{l}\text { p-tau } \downarrow \\
\text { p-PP2A, NR2A, } \\
\text { nissl bodies } \uparrow\end{array}$ & p-tau \\
\hline $\begin{array}{l}\text { An } \\
\text { et al. } \\
\text { (2018) }\end{array}$ & $\begin{array}{l}\text { SQYZ } \\
\text { granules }\end{array}$ & $\begin{array}{l}\text { Ginsenoside Rg1, } \\
\text { astragaloside a, and } \\
\text { baicalin }\end{array}$ & $A D$ & & $\begin{array}{l}\text { APP/PS1 double } \\
\text { transgenic mice }\end{array}$ & $\begin{array}{l}\text { A } 342, \\
\text { dynamin-1 } \downarrow \\
\text { MAPK3, TCA } \\
\text { (dalt, Fabp5, Idhb, } \\
\text { Glo1, } \\
\text { Eno1), HSP } \uparrow \\
\text { Atp5b, Dmxl1 }\end{array}$ & $\begin{array}{l}A \beta \text { deposition, } \\
\text { neuroinflammation, stress } \\
\text { responses, energy } \\
\text { metabolism }\end{array}$ \\
\hline $\begin{array}{l}\text { Ren } \\
\text { et al. } \\
\text { (2020) }\end{array}$ & $\begin{array}{l}\text { Shenqi yizhi } \\
\text { granules }\end{array}$ & $\begin{array}{l}\text { Panax ginseng, Astragalus } \\
\text { membranaceus, and } \\
\text { Scutellaria baicalensis } \\
\text { Georgi }(2: 4: 3)\end{array}$ & $A D$ & & $\begin{array}{l}\text { APP/PS1 double } \\
\text { transgenic mice }\end{array}$ & $\begin{array}{l}\text { Mdhc, PKM, } \\
\text { ATP, HSP } \uparrow \\
\text { acetyl-CoA }\end{array}$ & $\begin{array}{l}\text { Energy metabolism, stress } \\
\text { response, cytoskeleton, } \\
\text { synaptic transmission, signal } \\
\text { transduction, amino acid } \\
\text { metabolism }\end{array}$ \\
\hline $\begin{array}{l}\text { Guo } \\
\text { et al. } \\
(2019)\end{array}$ & Kai-xin-san & $\begin{array}{l}\text { Panax ginseng, Polygala } \\
\text { tenuifolia Willd, Poria } \\
\text { cocos (Schw.) Wolf, and } \\
\text { Acorus tatarinowii Schott } \\
(3: 2: 3: 2)\end{array}$ & $A D$ & $A \beta_{25-35}$ & SD rats/PC12 cells & 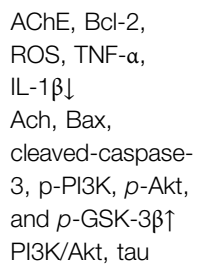 & $\begin{array}{l}\text { Oxidative stress, } \\
\text { neuroinflammation, } \\
\text { apoptosis, A } \beta \text { deposition, } \\
\text { cytoskeleton }\end{array}$ \\
\hline $\begin{array}{l}\text { Cao } \\
\text { et al. } \\
(2018)\end{array}$ & Kai-xin-san & $\begin{array}{l}\text { Ginseng Radix et } \\
\text { Rhizoma, Polygalae Radix, } \\
\text { Acori Tatarinowii, and } \\
\text { Poria (3:2:2:3) }\end{array}$ & & & $\begin{array}{l}\text { Primary mouse } \\
\text { astrocytes cells }\end{array}$ & $\begin{array}{l}\text { MMP-9, } \\
\text { TIMP-1 } \rightarrow \\
\text { NGF, BDNF, } \\
\text { CREB, tPA } \uparrow\end{array}$ & $\begin{array}{l}\text { CAMP-dependent pathway, } \\
\text { synthesis of neurotrophic } \\
\text { factors via regulation of the } \\
\text { tPA system }\end{array}$ \\
\hline $\begin{array}{l}\text { Liu } \\
\text { et al. } \\
\text { (2020) }\end{array}$ & $\begin{array}{l}\text { GAPT, } \\
\text { GEPT, or } \\
\text { jinsiwei }\end{array}$ & $\begin{array}{l}\text { Ginseng, epimedium, } \\
\text { polygala, and tuber } \\
\text { curcumae }\end{array}$ & $\begin{array}{l}\text { Learning and } \\
\text { memory-disordered } \\
\text { model }\end{array}$ & Scopolamine & $\begin{array}{l}6 \text { months old male } \\
\text { ICR mice }\end{array}$ & $\begin{array}{l}\text { MDA, } \\
\text { AChE, ROS } \downarrow \\
\text { ChAT, SOD, } \\
\text { GPX, Ach } \uparrow\end{array}$ & $\begin{array}{l}\text { Protecting cholinergic } \\
\text { neurons, reducing oxidative } \\
\text { stress injury, neuroprotective }\end{array}$ \\
\hline $\begin{array}{l}\text { Seo } \\
\text { et al. } \\
(2018)\end{array}$ & $\begin{array}{l}\text { P. montana } \\
\text { and red } \\
\text { ginseng } \\
\text { extracts }\end{array}$ & Hongshen and gegen & Neurodegeneration & TMT & $\begin{array}{l}5 \text { weeks old male } \\
\text { ICR mice }\end{array}$ & $\begin{array}{l}\text { AChE } \downarrow \\
\text { Catalase, MDA } \uparrow\end{array}$ & Ach, oxidative stresses \\
\hline $\begin{array}{l}\text { Shi } \\
\text { et al. } \\
\text { (2018) }\end{array}$ & $\begin{array}{l}\text { Rg1 and } \\
\text { Acori } \\
\text { graminei } \\
\text { Rhizoma }\end{array}$ & $\begin{array}{l}\text { Ginsenoside Rg1 and } \\
\text { shichangpu }\end{array}$ & $A D$ & $\mathrm{~A} \beta_{1-42}$ & $\begin{array}{l}\text { SAMP8 mice/ } \\
\text { Primary } \\
\text { hippocampal } \\
\text { neurons cells/PC12 } \\
\text { cells }\end{array}$ & 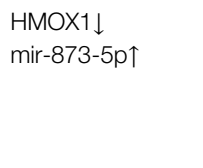 & Apoptosis \\
\hline
\end{tabular}

suppress pro-inflammatory mediators, and caspase-3/PARP-1 signaling, inhibiting mitochondria-mediated apoptosis and protecting against $A \beta$-induced injury (Lee et al., 2017). In addition, the nonsaponin polysaccharide fraction, from ginseng, mitigates $\mathrm{A} \beta$-induced neuronal dysfunction and improves mitochondrial respiration in the subiculum of the $5 \times$ FAD mice model (Shin et al., 2021). Collectively, these results indicate that ginseng extracts and fractions have neuroprotective roles, improving mitochondrial dysfunction and inhibiting inflammation and apoptosis (Table 2). Importantly, the active components of these ginseng extracts should be further identified.

\section{Formulas Containing Ginseng or Combination Treatment}

Formulas containing ginseng and drug combinations can be used to achieve treatment efficacy and reduced toxicity. Currently, several decoctions containing ginseng are investigated to confirm the neuroprotective effects and identify the active components. Fuzheng Quxie decoction includes ginsenosides Rg1, Re, Rb1, and coptisine, which can cross the blood-brain barrier to inhibit tau hyperphosphorylation in the hippocampus, inhibiting learning and memory impairments in SAMP8 mice (Yang et al., 2017). The anti-neuroinflammatory effects of the Shenqi Yizhi formula in the $5 \times$ FAD mice model may be mediated by active components including ginsenoside $\mathrm{Rg} 1$, astragaloside $\mathrm{A}$, and baicalin by influencing energy metabolism, cytoskeleton, and stress reaction (An et al., 2018; Ren et al., 2020). Shengmai San can inhibit $A \beta_{1-42}$ production to improve spatial learning and memory of APP/PS1 mice (Zhang et al., 2018). Kaixin San (KXS), a well-known formula that has been used in clinical settings for a long time, has various pharmacological effects; for instance, protecting nerve cells and preventing AD (Lv et al., 2014; Wang et al., 2019). The active components of KXS have been identified as ginsenoside $\mathrm{Rf}$, ginsenoside $\mathrm{F} 1$, and 


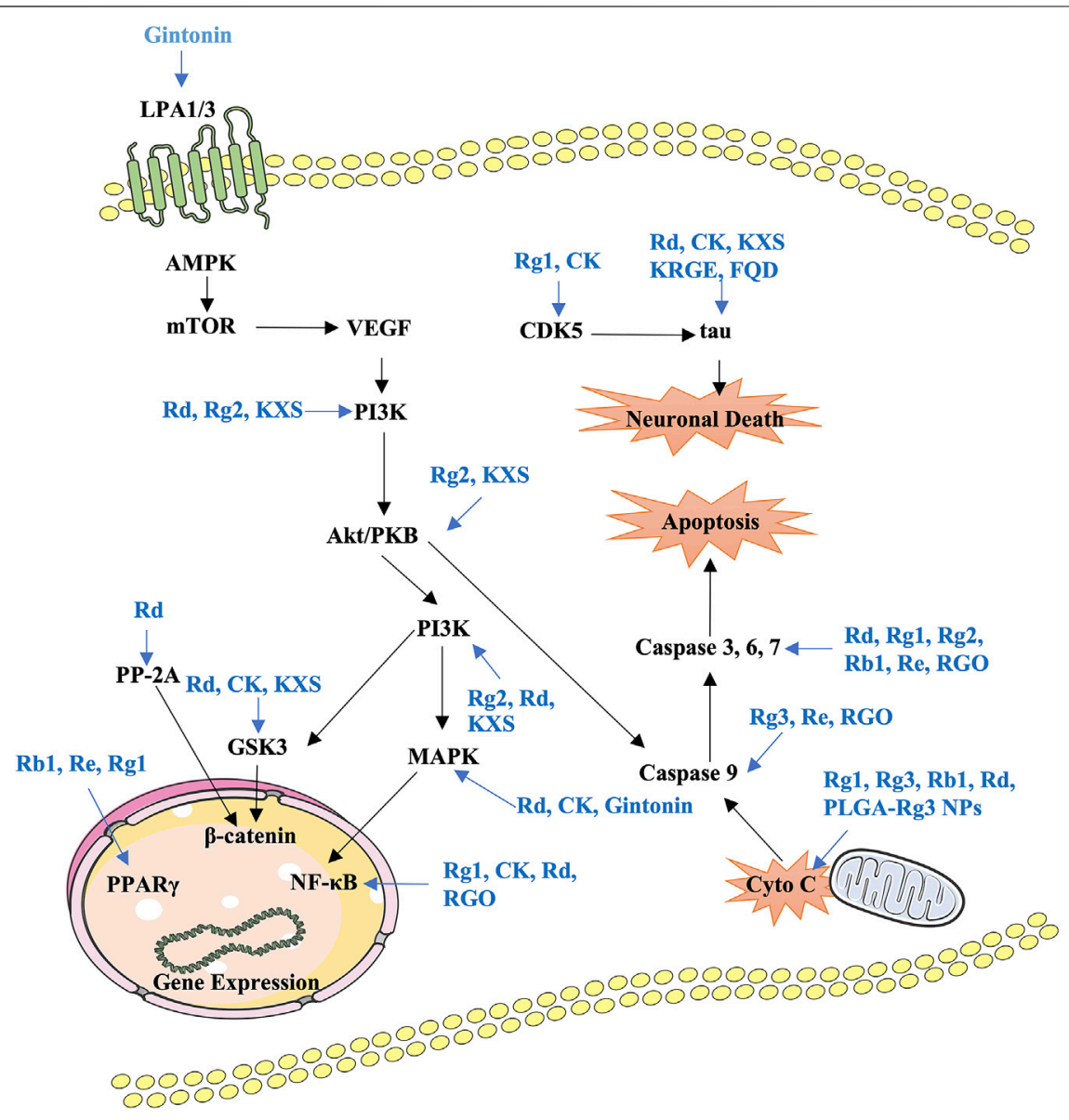

FIGURE 2 | Summary of the functional effects of ginseng on AD via multiple links across regulatory mechanisms and multitarget effects. LPA, lysophosphatidic acid; KXS, Kaixin-San; PP-2A, protein phosphatase 2A; RGO, red Ginseng oil; Cyto C, cytochrome C.

dehydropachymic acid, which can activate cAMP-dependent signaling and promote neurotrophic factor synthesis in primary astrocytes and $\mathrm{AD}$ mice (Cao et al., 2018; Wang et al., 2019). Importantly, system biology analysis has validated that KXS has multitarget synergistic effects on the amelioration of AD features (Guo et al., 2019). Ninjin-yoei-to (NYT), a formula containing 14 herbs, can promote the production of nerve growth factor in rat embryo astrocytes after incubation for $24 \mathrm{~h}$ (Yabe et al., 2003). Additionally, GAPT (Jinsiwei), a combination of several active components, can reduce the AChE activity and expression and increase ACh synthesis to improve cholinergic nerve function, reducing the learning and memory impairments in scopolamine-induced mice (Liu et al., 2020). Pretreatment with $P$. montana and red ginseng extracts significantly reduces catalase and $\mathrm{AChE}$ activities, inhibiting trimethyltin-induced neuronal cell death, oxidative stress, and learning and memory impairments (Seo et al., 2018). Ginsenoside Rg1 combined with the Acori graminei rhizoma extract can reverse the effect of $A \beta_{1-42}$ accumulation by regulating the expression of miR-873$5 p$ in PC12 cells and SAMP8 mice (Shi et al., 2018). The current findings of formulas or combination treatment in $\mathrm{AD}$ have been summarized in Table 3. In vitro and in vivo preclinical studies have demonstrated that ginsenosides, gintonin, and other active components from ginseng or formulas containing ginseng mainly regulate PI3K/Akt, AMPK-mTOR, MAPK, GSK-3 $\beta /$ CDK5, NF$\kappa \mathrm{B}$, and mitochondrial apoptotic signaling pathways to improve key pathological processes of $\mathrm{AD}$ development (Figure 2).

\section{CLINICAL TRIALS OF GINSENG, FORMULAS, OR DIETARY SUPPLEMENTS CONTAINING GINSENG}

At present, very few clinical trials investigating the effects of ginseng intervention on $\mathrm{AD}$ are ongoing or completed. Most clinical trials focus on ginseng or red ginseng extract and employ the Alzheimer's Disease Assessment Scale (ADAS) and the MiniMental State Examination (MMSE) scores to monitor cognitive performances. After ginseng treatment for 12 weeks, the cognitive subscale of ADAS and the MMSE score are significantly improved, indicating that ginseng has positive effect on the cognitive performance of AD patients (Lee et al., 2008). After administration with heat-processed ginseng ( $4.5 \mathrm{~g} /$ day) for 24 weeks, cognitive function and behavioral symptoms in patients 
TABLE 4 | Summary of clinical trials of ginseng interventions in AD patients.

\begin{tabular}{|c|c|c|c|c|c|c|}
\hline Ref & Medicine & Model & Sample size & Inclusion criteria & $\begin{array}{l}\text { Evaluative } \\
\text { criteria }\end{array}$ & Results \\
\hline $\begin{array}{l}\text { Lee et al. } \\
\text { (2008) }\end{array}$ & Ginseng & $A D$ & $\begin{array}{l}\text { Control group ( } n=39) \text {, } \\
\text { ginseng group }(n=58)\end{array}$ & $\begin{array}{l}\text { 1. NINDS-ADRDA } \\
\text { 2. Patients without other } \\
\text { neurodegenerative disorders or } \\
\text { cognitive impairments } \\
\text { 3. The use of drugs for concomitant } \\
\text { conditions was permitted }\end{array}$ & MMSE, ADAS & $\begin{array}{l}\text { Ginseng as a cognitive enhancer } \\
\text { for } A D \text { patients }\end{array}$ \\
\hline $\begin{array}{l}\text { Kudoh } \\
\text { et al. } \\
(2016)\end{array}$ & $\begin{array}{l}\text { Ninjin-yoei-to (renshen } \\
\text { yangrong tang) }\end{array}$ & $\begin{array}{l}\text { Mild to } \\
\text { moderate } \\
\text { probable AD }\end{array}$ & $\begin{array}{l}\text { Donepezil }(n=11) \\
\text { donepezil }+ \text { NYT } \\
(n=12)\end{array}$ & $\begin{array}{l}\text { 1. Patients diagnosed with AD } \\
\text { between } 65 \text { and } 85 \text { years of age } \\
\text { 2. Patients who scored } 15-23 \\
\text { points on the MMSE after treatment } \\
\text { with donepezil ( } 5 \mathrm{mg} / \text { day) for more } \\
\text { than } 8 \text { months, but who did not } \\
\text { exhibit any significant change in } \\
\text { cognitive function } \\
\text { 3. Patients without an otherwise } \\
\text { healthy condition }\end{array}$ & $\begin{array}{l}\text { MMSE, } \\
\text { ADAS-J } \\
\text { cog, NPI }\end{array}$ & $\begin{array}{l}\text { No significant differences } \\
\text { between the two groups }\end{array}$ \\
\hline $\begin{array}{l}\text { Heo et al. } \\
(2012)\end{array}$ & $\begin{array}{l}\text { Heat-processed } \\
\text { ginseng }\end{array}$ & $A D$ & $\begin{array}{l}1.5 \mathrm{~g} / \text { day }(n=10), 3 \mathrm{~g} / \\
\text { day }(n=10), 4.5 \mathrm{~g} / \text { day } \\
(n=10), \text { control }(n=10)\end{array}$ & $\begin{array}{l}\text { 1. Age older than } 50 \text { years } \\
\text { 2. MMSE score of } \leq 20 \\
\text { 3. CDR score of } \geq 1 \\
\text { 4. Without psychiatric disorder, } \\
\text { seizure disorder, or a medical } \\
\text { condition } \\
\text { 5. Without cognitive impairment due } \\
\text { to stroke, neoplasia, infection, } \\
\text { hypoxic brain injury, or medications }\end{array}$ & ADAS, MMSE & $\begin{array}{l}\text { Significant improvement on the } \\
\text { MMSE and ADAS. Higher dose } \\
\text { group ( } 4.5 \mathrm{~g} / \text { day) showed } \\
\text { improvements in ADAS and } \\
\text { MMSE score as early as at } \\
12 \text { weeks, which sustained for } \\
24 \text {-week follow-up }\end{array}$ \\
\hline $\begin{array}{l}\text { Heo et al. } \\
(2008)\end{array}$ & Korean red ginseng & $A D$ & $\begin{array}{l}\text { Low-dose (4.5 g/day, } \mathrm{n} \\
=15), \text { high-dose }(9 \mathrm{~g} / \\
\text { day, } \mathrm{n}=15), \text { control }(\mathrm{n} \\
=31)\end{array}$ & $\begin{array}{l}\text { 1. Aged older than } 50 \text { years and } \\
\text { baseline MMSE score of } \geq 10 \\
\text { and } \leq 26 \\
\text { 2. Patients were without psychiatric } \\
\text { disorder, seizure disorder, or a } \\
\text { medical condition that would limit } \\
\text { the completeness of the study } \\
\text { 3. Patients without cognitive } \\
\text { disorder caused by stroke, hypoxic } \\
\text { brain, cerebral neoplasia, infection, } \\
\text { and medications }\end{array}$ & $\begin{array}{l}\text { ADAS, } \\
\text { K-MMSE, } \\
\text { CDR }\end{array}$ & $\begin{array}{l}\text { High-dose KRG group was } \\
\text { significant improvement on the } \\
\text { ADAS and CDR but normally } \\
\text { improved on the MMSE after } \\
12 \text { weeks of KRG therapy when } \\
\text { compared with those in the } \\
\text { control group }\end{array}$ \\
\hline $\begin{array}{l}\text { Yakoot } \\
\text { et al. } \\
\text { (2013) }\end{array}$ & $\begin{array}{l}\text { Memo }{ }^{\circledR} \text { (combining of } \\
\text { lyophilized royal jelly, } \\
\text { extracts of G. biloba } \\
\text { and P. ginseng) }\end{array}$ & $A D$ & $\begin{array}{l}\text { Experimental group }(\mathrm{n}= \\
30) \text { control group }(\mathrm{n} \\
=30)\end{array}$ & $\begin{array}{l}\text { 1. Aged } 50-80 \text { years, complaining } \\
\text { of memory impairment or } \\
\text { forgetfulness } \\
\text { 2. Satisfying the clinical criteria of } \\
\text { memory complaint, normal activities } \\
\text { of daily living, abnormal memory for } \\
\text { age, and no documented dementia }\end{array}$ & MMSE & $\begin{array}{l}\text { Beneficial in treating the } \\
\text { cognitive decline that occurs } \\
\text { during the aging process as well } \\
\text { as in the early stages of } \\
\text { pathologic cognitive impairment } \\
\text { of insidious-onset vascular } \\
\text { dementia and in AD }\end{array}$ \\
\hline
\end{tabular}

with moderately severe $\mathrm{AD}$ are improved at 12 weeks, which is sustained for the next 12-week follow-up (Heo et al., 2012). AD patients in the high-dose $(9 \mathrm{~g} /$ day) Korean red ginseng group show significant improvements on the ADAS and Clinical Dementia Rating scales after 12-week therapy compared with the control group (Heo et al., 2008). In a larger-sized study, oral administration of $\mathrm{Memo}{ }^{\circledR}$, a triple formula $(750 \mathrm{mg}$ lyophilized royal jelly, $120 \mathrm{mg}$ Ginkgo biloba extract, and $150 \mathrm{mg}$ ginseng extract) for 4 weeks was shown to exert beneficial effects on cognition during aging and pathologic cognitive impairment in the early stages of AD (Yakoot et al., 2013). Furthermore, a combination of NYT and donepezil is more effective for AD patients with mild depression compared with donepezil-only (Kudoh et al., 2016). In addition, no adverse reactions occurred in all clinical studies, which suggests that ginseng can be used safely and has better tolerance for the patients with AD. The findings from clinical trials have been summarized in Table 4, which preliminarily indicates that ginseng treatment is safe and has a positive effect on cognition in patients with AD. However, it is essential to conduct more and high-quality clinical trials to evaluate the protective and therapeutic effects of ginseng, formulas containing ginseng, and combinations with other drugs in patients with different stages of $\mathrm{AD}$ and explore the underlying molecular mechanisms.

\section{CONCLUSION}

In this review, we summarize our recent findings regarding the effects of ginseng on $\mathrm{AD}$ and cognitive and memory dysfunction. 


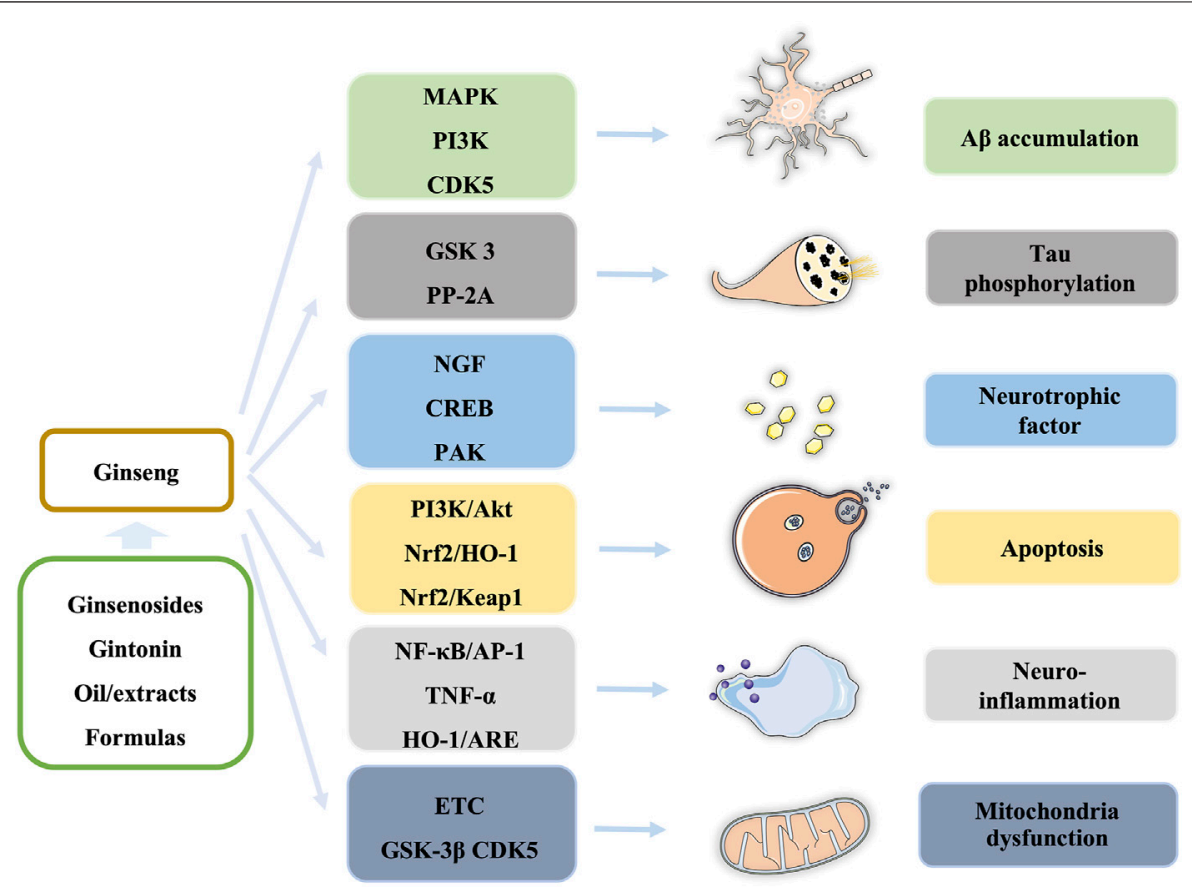

FIGURE 3 | Summary of ginseng components and the affected pathways in the pathological process of AD.

Ginsenosides, gintonin, extracts/fractions from ginseng, and formulas containing ginseng are widely studied in cells and animal models, which demonstrate that ginseng exerts neuroprotective effects in the prevention and treatment of $\mathrm{AD}$ through regulating multiple signaling pathways, such as PI3K/ Akt, AMPK-mTOR, and NF- $\kappa \mathrm{B}$ pathways, to block or improve pathological processes, including $A \beta$ accumulation, tau phosphorylation, neuroinflammation, neurotrophic factors, apoptosis, and mitochondrial dysfunction in different stages of $\mathrm{AD}$ (Figure 3).

However, in preclinical and clinical studies of the effects of ginseng on $\mathrm{AD}$, three important aspects should be considered: 1) Most studies focus on ginsenosides and gintonin with different chemical characteristics. The molecular mechanisms underlying the effects of ginsenosides and gintonin in the regulation of $\mathrm{A} \beta$ accumulation, neuroinflammation, and neurotrophic factors are similar, but only gintonin can interact with LPA receptors to mediate transient increases in $\left[\mathrm{Ca}^{2+}\right] \mathrm{i}$ regulating neurotransmitter release and improving cognition. 2) A series of cell models, such as PC12, SH-SY5Y, SweAPP-SK, and hippocampal neurons and several animal models, such as SAMP8, $5 \times \mathrm{FAD}$, and $3 \times \mathrm{Tg}$-AD mice are used to evaluate the neuroprotective effects of ginseng. Based on the current preclinical findings, we think that long-term interventions with ginseng or its formulas are critical to improve cognitive features for $\mathrm{AD}$ patients in early stages, which should be validated in larger and multicenter clinical trials. 3) Key pathological procedures of
$\mathrm{AD}$, including $\mathrm{A} \beta$ synthesis and degradation, neurotoxicity, and mitochondrial function, are potential targets for ginseng treatments. However, the molecular targets and binding sites of ginsenosides, gintonin, and other components in the prevention and treatment of $\mathrm{AD}$ remain unclear. Therefore, the network of targets of ginseng needs to be explored in the future. Collectively, this review can provide new insights into the possible use of ginseng in the prevention and treatment of $\mathrm{AD}$.

\section{AUTHOR CONTRIBUTIONS}

JinL and QH collected, analyzed, and reviewed the literature and wrote the main manuscript; JinL, JC, HQ, JiaL, and ZC added/ checked references and assembled figures/tables; DZ and ZW revised the manuscript; XL and ZW designed and supervised the final version of the manuscript. All authors have read and agreed to the published version of the manuscript.

\section{FUNDING}

This study was supported by the National Key Research and Development Program of China (2017YFC1702103), National Natural Science Foundation of China (U19A2013), and Science and Technology Development Plan Project of Jilin Province (20190101010JH, 202002053JC). 


\section{REFERENCES}

Aalinkeel, R., Kutscher, H. L., Singh, A., Cwiklinski, K., Khechen, N., Schwartz, S. A., et al. (2018). Neuroprotective Effects of a Biodegradable Poly(lactic-CoGlycolic Acid)-Ginsenoside Rg3 Nanoformulation: a Potential Nanotherapy for Alzheimer's Disease?. J. Drug Target. 26, 182-193. doi:10.1080/1061186x.2017. 1354002

Alzheimer's Association (2020). Alzheimer's Disease Facts and Figures. Alzheimer's \& Dementia: The Journal of the Alzheimer's Association.

An, H., Wei, D., Qian, Y., Li, N., and Wang, X. (2018). SQYZ Granules, a Traditional Chinese Herbal, Attenuate Cognitive Deficits in AD Transgenic Mice by Modulating on Multiple Pathogenesis Processes. Am. J. Transl Res. 10, 3857-3875.

Arendt, T., and Bullmann, T. (2013). Neuronal Plasticity in Hibernation and the Proposed Role of the Microtubule-Associated Protein Tau as a "master Switch" Regulating Synaptic Gain in Neuronal Networks. Am. J. Physiol. Regulatory, Integr. Comp. Physiol. 305, R478-R489. doi:10.1152/ajpregu. 00117.2013

Bader Lange, M. L., Cenini, G., Piroddi, M., Mohmmad Abdul, H., Sultana, R., Galli, F., et al. (2008). Loss of Phospholipid Asymmetry and Elevated Brain Apoptotic Protein Levels in Subjects with Amnestic Mild Cognitive Impairment and Alzheimer Disease. Neurobiol. Dis. 29, 456-464. doi:10.1016/j.nbd.2007. 11.004

Cao, C., Xiao, J., Liu, M., Ge, Z., Huang, R., Qi, M., et al. (2018). Active Components, Derived from Kai-Xin-San, a Herbal Formula, Increase the Expressions of Neurotrophic Factor NGF and BDNF on Mouse Astrocyte Primary Cultures via cAMP-dependent Signaling Pathway. J. Ethnopharmacol. 224, 554-562. doi:10.1016/j.jep.2018.06.007

Cao, G., Su, P., Zhang, S., Guo, L., Zhang, H., Liang, Y., et al. (2016). Ginsenoside Re Reduces $A \beta$ Production by Activating PPAR $\gamma$ to Inhibit BACE1 in N2a/ APP695 Cells. Eur. J. Pharmacol. 793, 101-108. doi:10.1016/j.ejphar.2016. 11.006

Changhong, K., Peng, Y., Yuan, Z., and Cai, J. (2021). Ginsenoside Rb1 Protected PC12 Cells from A $325-35-$ Induced Cytotoxicity via PPAR $\gamma$ Activation and Cholesterol Reduction. Eur. J. Pharmacol. 893, 173835. doi:10.1016/j.ejphar. 2020.173835

Chen, F., Eckman, E. A., Eckman, C. B., Chen, F., Eckman, E. A., and Eckman, C. B. (2006). Reductions in Levels of the Alzheimer's Amyloid $\beta$ Peptide after Oral Administration of Ginsenosides. FASEB j. 20, 1269-1271. doi:10.1096/fj.055530fje

Chen, X., Li, H., Yang, Q., Lan, X., Wang, J., Cao, Z., et al. (2019). Ginsenoside Compound K Ameliorates Alzheimer's Disease in HT22 Cells by Adjusting Energy Metabolism. Mol. Biol. Rep. 46, 5323-5332. doi:10.1007/s11033-01904988-0

Choi, S.-H., Kim, H.-J., Cho, H.-J., Park, S.-D., Lee, N.-E., Hwang, S.-H., et al. (2019). Gintonin-mediated Release of Astrocytic Vascular Endothelial Growth Factor Protects Cortical Astrocytes from Hypoxia-Induced Cell Damages. J. ginseng Res. 43, 305-311. doi:10.1016/j.jgr.2018.05.006

Choi, S.-H., Lee, R., Nam, S. M., Kim, D.-G., Cho, I.-H., Kim, H.-C., et al. (2021). Ginseng Gintonin, Aging Societies, and Geriatric Brain Diseases. Integr. Med. Res. 10, 100450. doi:10.1016/j.imr.2020.100450

Choi, S., Jung, S., Lee, B., Kim, H., Hwang, S., Kim, H., et al. (2015). Ginseng Pharmacology: a New Paradigm Based on Gintonin-Lysophosphatidic Acid Receptor Interactions. Front. Pharmacol. 6, 245. doi:10.3389/fphar.2015.00245

Cui, J., Shan, R., Cao, Y., Zhou, Y., Liu, C., and Fan, Y. (2020). Protective Effects of Ginsenoside Rg2 against Memory Impairment and Neuronal Death Induced by A $325-35$ in Rats. J. Ethnopharmacol 266, 113466. doi:10.1016/j.jep.2020.113466

Cui, J., Wang, J., Zheng, M., Gou, D., Liu, C., and Zhou, Y. (2017). Ginsenoside Rg2 Protects PC12 Cells against $\beta$-amyloid25-35-induced Apoptosis via the Phosphoinositide 3-kinase/Akt Pathway. Chemico-Biological Interactions 275, 152-161. doi:10.1016/j.cbi.2017.07.021

Cummings, J. (2021). New Approaches to Symptomatic Treatments for Alzheimer's Disease. Mol. Neurodegener 16, 2. doi:10.1186/s13024-02100424-9

Du, Y., Fu, M., Wang, Y. T., and Dong, Z. (2018). Neuroprotective Effects of Ginsenoside Rf on Amyloid- $\beta$-Induced Neurotoxicity In Vitro and In Vivo. Jad 64, 309-322. doi:10.3233/jad-180251
Gomes, L. A., Hipp, S. A., Rijal Upadhaya, A., Balakrishnan, K., Ospitalieri, S. Koper, M. J., et al. (2019). A $\beta$-induced Acceleration of Alzheimer-Related $\tau$-pathology Spreading and its Association with Prion Protein. Acta Neuropathol. 138, 913-941. doi:10.1007/s00401-019-02053-5

Guo, M., Shao, S., Wang, D., Zhao, D., and Wang, M. (2021). Recent Progress in Polysaccharides from Panax Ginseng C. A. Meyer. Food Funct. 12, 494-518. doi:10.1039/d0fo01896a

Guo, S., Wang, J., Wang, Y., Zhang, Y., Bi, K., Zhang, Z., et al. (2019). Study on the Multitarget Synergistic Effects of Kai-Xin-San against Alzheimer's Disease Based on Systems Biology. Oxid Med. Cel Longev 2019, 1707218. doi:10. $1155 / 2019 / 1707218$

Han, J., Oh, J. P., Yoo, M., Cui, C. H., Jeon, B. M., Kim, S. C., et al. (2019). Minor Ginsenoside F1 Improves Memory in APP/PS1 Mice. Mol. Brain 12, 77. doi:10. 1186/s13041-019-0495-7

Heo, J.-H., Lee, S.-T., Chu, K., Oh, M. J., Park, H.-J., Shim, J.-Y., et al. (2008). An Open-Label Trial of Korean Red Ginseng as an Adjuvant Treatment for Cognitive Impairment in Patients with Alzheimers Disease. Eur. J. Neurol. 15, 865-868. doi:10.1111/j.1468-1331.2008.02157.x

Heo, J.-H., Lee, S.-T., Chu, K., Oh, M. J., Park, H.-J., Shim, J.-Y., et al. (2012). Heatprocessed Ginseng Enhances the Cognitive Function in Patients with Moderately Severe Alzheimer's Disease. Nutr. Neurosci. 15, 278-282. doi:10. 1179/1476830512y.0000000027

Hwang, S. H., Shin, E.-J., Shin, T.-J., Lee, B.-H., Choi, S.-H., Kang, J., et al. (2012). Gintonin, a Ginseng-Derived Lysophosphatidic Acid Receptor Ligand, Attenuates Alzheimer's Disease-Related Neuropathies: Involvement of Nonamyloidogenic Processing. Jad 31, 207-223. doi:10.3233/jad-2012-120439

Ikram, M., Ullah, R., Khan, A., and Kim, M. O. (2020). Ongoing Research on the Role of Gintonin in the Management of Neurodegenerative Disorders. Cells 9. doi: $10.3390 /$ cells 9061464

Im, D.-s., and Nah, S.-y. (2013). Yin and Yang of Ginseng Pharmacology: Ginsenosides vs Gintonin. Acta Pharmacol. Sin 34, 1367-1373. doi:10.1038/ aps.2013.100

Jakaria, M., Azam, S., Go, E. A., Uddin, M. S., Jo, S. H., and Choi, D. K. (2020). Biological Evidence of Gintonin Efficacy in Memory Disorders. Pharmacol. Res. 163, 105221. doi:10.1016/j.phrs.2020.105221

JeffKuret, N. S. H. a. (2008). Tau Aggregation and Toxicity in Tauopathic Neurodegenerative Diseases. J. Alzheimer's Dis. 14, 417-422. doi:10.3233/ jad-2008-14409

Jia, J., Wei, C., Chen, S., Li, F., Tang, Y., Qin, W., et al. (2018). The Cost of Alzheimer's Disease in China and Re-estimation of Costs Worldwide. Alzheimer's Demen. 14, 483-491. doi:10.1016/j.jalz.2017.12.006

Jia, L., Quan, M., Fu, Y., Zhao, T., Li, Y., Wei, C., et al. (2020). Dementia in China: Epidemiology, Clinical Management, and Research Advances. Lancet Neurol. 19, 81-92. doi:10.1016/s1474-4422(19)30290-x

Johansson, M., Stomrud, E., Lindberg, O., Westman, E., Johansson, P. M., van Westen, D., et al. (2020). Apathy and Anxiety Are Early Markers of Alzheimer's Disease. Neurobiol. Aging 85, 74-82. doi:10.1016/j.neurobiolaging.2019. 10.008

Joo, S. S., Yoo, Y. M., Ahn, B. W., Nam, S. Y., Kim, Y.-B., Hwang, K. W., et al. (2008). Prevention of Inflammation-Mediated Neurotoxicity by Rg3 and its Role in Microglial Activation. Biol. Pharm. Bull. 31, 1392-1396. doi:10.1248/ bpb.31.1392

Kareti, S. R., and P, S. (2020). In Silico Molecular Docking Analysis of Potential Anti-alzheimer's Compounds Present in Chloroform Extract of Carissa Carandas Leaf Using Gas Chromatography MS/MS. Curr. Ther. Res. 93, 100615. doi:10.1016/j.curtheres.2020.100615

Karpagam, V., Sathishkumar, N., Sathiyamoorthy, S., Rasappan, P., Shila, S., Kim, Y.-J., et al. (2013). Identification of BACE1 Inhibitors from Panax Ginseng Saponins-An Insilco Approach. Comput. Biol. Med. 43, 1037-1044. doi:10. 1016/j.compbiomed.2013.05.009

Kim, H.-J., Jung, S.-W., Kim, S.-Y., Cho, I.-H., Kim, H.-C., Rhim, H., et al. (2018). Panax Ginseng as an Adjuvant Treatment for Alzheimer's Disease. J. Ginseng Res. 42, 401-411. doi:10.1016/j.jgr.2017.12.008

Kim, H.-J., Kim, D.-J., Shin, E.-J., Lee, B.-H., Choi, S.-H., Hwang, S.-H., et al. (2016). Effects of Gintonin-Enriched Fraction on Hippocampal Cell Proliferation in Wild-type Mice and an APPswe/PSEN-1 Double Tg Mouse Model of Alzheimer's Disease. Neurochem. Int. 101, 56-65. doi:10.1016/j. neuint.2016.10.006 
Kim, H.-J., Shin, E.-J., Lee, B.-H., Choi, S.-H., Jung, S.-W., Cho, I.-H., et al. (2015a). Oral Administration of Gintonin Attenuates Cholinergic Impairments by Scopolamine, Amyloid- $\beta$ Protein, and Mouse Model of Alzheimer's Disease. Mol. Cell 38, 796-805. doi:10.14348/molcells.2015.0116

Kim, H., Lee, B.-H., Choi, S.-H., Kim, H.-J., Jung, S.-W., Hwang, S.-H., et al. (2015b). Gintonin Stimulates Gliotransmitter Release in Cortical Primary Astrocytes. Neurosci. Lett. 603, 19-24. doi:10.1016/j.neulet.2015.07.012

Kim, M. S., Yu, J. M., Kim, H. J., Kim, H. B., Kim, S. T., Jang, S. K., et al. (2014). Ginsenoside Re and Rd Enhance the Expression of Cholinergic Markers and Neuronal Differentiation in Neuro-2a Cells. Biol. Pharm. Bull. 37, 826-833. doi:10.1248/bpb.b14-00011

Kudoh, C., Arita, R., Honda, M., Kishi, T., Komatsu, Y., Asou, H., et al. (2016). Effect of Ninjin'yoeito, a Kampo (Traditional Japanese) Medicine, on Cognitive Impairment and Depression in Patients with Alzheimer's Disease: 2 Years of Observation. Psychogeriatrics 16, 85-92. doi:10.1111/psyg.12125

Kwon, O. H., Cho, Y. Y., Kim, T.-W., and Chung, S. (2019). O-GlcNAcylation of Amyloid- $\beta$ Protein Precursor by Insulin Signaling Reduces Amyloid- $\beta$ Production. Jad 69, 1195-1211. doi:10.3233/jad-190060

Lee, B.-H., Choi, S.-H., Kim, H.-J., Park, S.-D., Rhim, H., Kim, H.-C., et al. (2018a). Gintonin Absorption in Intestinal Model Systems. J. Ginseng Res. 42, 35-41. doi:10.1016/j.jgr.2016.12.007

Lee, B., Sur, B., Park, J., Kim, S.-H., Kwon, S., Yeom, M., et al. (2013). Ginsenoside Rg3 Alleviates Lipopolysaccharide-Induced Learning and Memory Impairments by Anti-inflammatory Activity in Rats. Biomolecules Ther. 21, 381-390. doi:10.4062/biomolther.2013.053

Lee, S.-T., Chu, K., Sim, J.-Y., Heo, J.-H., and Kim, M. (2008). Panax Ginseng Enhances Cognitive Performance in Alzheimer Disease. Alzheimer Dis. Assoc. Disord. 22, 222-226. doi:10.1097/wad.0b013e31816c92e6

Lee, S., Youn, K., Jeong, W., Ho, C., and Jun, M. (2017). Protective Effects of Red Ginseng Oil against $\mathrm{A} \beta$-Induced Neuronal Apoptosis and Inflammation in PC12 Cells. Int. J. Mol. Sci. 18. doi:10.3390/ijms18102218

Lee, S., Youn, K., and Jun, M. (2018b). Major Compounds of Red Ginseng Oil Attenuate A $325-35$-Induced Neuronal Apoptosis and Inflammation by Modulating MAPK/NF-KB Pathway. Food Funct. 9, 4122-4134. doi:10.1039/ c8fo00795k

Li, G., Zhang, N., Geng, F., Liu, G., Liu, B., Lei, X., et al. (2019). High-throughput Metabolomics and Ingenuity Pathway Approach Reveals the Pharmacological Effect and Targets of Ginsenoside Rg1 in Alzheimer's Disease Mice. Sci. Rep. 9, 7040. doi:10.1038/s41598-019-43537-4

Li, J., Liu, Y., Li, W., Wang, Z., Guo, P., Li, L., et al. (2018). Metabolic Profiling of the Effects of Ginsenoside Re in an Alzheimer's Disease Mouse Model. Behav. Brain Res. 337, 160-172. doi:10.1016/j.bbr.2017.09.027

Li, L., Liu, J., Yan, X., Qin, K., Shi, M., Lin, T., et al. (2011). Protective Effects of Ginsenoside Rd against Okadaic Acid-Induced Neurotoxicity In Vivo and In Vitro. J. Ethnopharmacol. 138, 135-141. doi:10.1016/j.jep.2011.08.068

Li, L., Liu, Z., Liu, J., Tai, X., Hu, X., Liu, X., et al. (2013). Ginsenoside Rd Attenuates Beta-Amyloid-Induced Tau Phosphorylation by Altering the Functional Balance of Glycogen Synthase Kinase 3beta and Protein Phosphatase 2A. Neurobiol. Dis. 54, 320-328. doi:10.1016/j.nbd.2013.01.002

Li, N., Liu, B., Dluzen, D. E., and Jin, Y. (2007). Protective Effects of Ginsenoside Rg2 against Glutamate-Induced Neurotoxicity in PC12 Cells. J. Ethnopharmacol. 111, 458-463. doi:10.1016/j.jep.2006.12.015

Lin, J., Gao, S., Wang, T., Shen, Y., Yang, W., Li, Y., et al. (2019). Ginsenoside Rb1 Improves Learning and Memory Ability through its Anti-inflammatory Effect in A $\beta 1-40$ Induced Alzheimer's Disease of Rats. Am. J. Transl Res. 11, $2955-2968$.

Liu, J.-f., Yan, X.-d., Qi, L.-s., Li, L., Hu, G.-y., Li, P., et al. (2015b). Ginsenoside Rd Attenuates A 325 -35-Induced Oxidative Stress and Apoptosis in Primary Cultured Hippocampal Neurons. Chemico-Biological Interactions 239, 12-18. doi:10.1016/j.cbi.2015.06.030

Liu, J., Yan, X., Li, L., Li, Y., Zhou, L., Zhang, X., et al. (2015a). Ginsenoside Rd Improves Learning and Memory Ability in APP Transgenic Mice. J. Mol. Neurosci. 57, 522-528. doi:10.1007/s12031-015-0632-4

Liu, J., Yan, X., Li, L., Zhu, Y., Qin, K., Zhou, L., et al. (2012). Ginsennoside Rd Attenuates Cognitive Dysfunction in a Rat Model of Alzheimer's Disease. Neurochem. Res. 37, 2738-2747. doi:10.1007/s11064-012-0866-2

Liu, M., Bai, X., Yu, S., Zhao, W., Qiao, J., Liu, Y., et al. (2019). Ginsenoside Re Inhibits ROS/ASK-1 Dependent Mitochondrial Apoptosis Pathway and
Activation of Nrf2-Antioxidant Response in Beta-Amyloid-Challenged SHSy5y Cells. Molecules 24. doi:10.3390/molecules24152687

Liu, Z., Qin, G., Mana, L., Dong, Y., Huang, S., Wang, Y., et al. (2020). GAPT Regulates Cholinergic Dysfunction and Oxidative Stress in the Brains of Learning and Memory Impairment Mice Induced by Scopolamine. Brain Behav. 10, e01602. doi:10.1002/brb3.1602

Lv, C., Li, Q., Zhang, X., He, B., Xu, H., Yin, Y., et al. (2014). Simultaneous Quantitation of Polygalaxanthone III and Four Ginsenosides by Ultra-fast Liquid Chromatography with Tandem Mass Spectrometry in Rat and Beagle Dog Plasma after Oral Administration of Kai-Xin-San: Application to a Comparative Pharmacokinetic S. J. Sep. Sci. 37, 1103-1110. doi:10.1002/jssc. 201400058

Nah, S.-Y. (2012). Gintonin: a Novel Ginseng-Derived Ligand that Targets G Protein- Coupled Lysophosphatidic Acid Receptors. Cdt 13, 1659-1664. doi:10. 2174/138945012803529947

Nie, L., Xia, J., Li, H., Zhang, Z., Yang, Y., Huang, X., et al. (2017). Ginsenoside Rg1 Ameliorates Behavioral Abnormalities and Modulates the Hippocampal Proteomic Change in Triple Transgenic Mice of Alzheimer's Disease. Oxid Med. Cel Longev 2017, 6473506. doi:10.1155/2017/6473506

Oh, J., and Kim, J.-S. (2016). Compound K Derived from Ginseng: Neuroprotection and Cognitive Improvement. Food Funct. 7, 4506-4515. doi:10.1039/c6fo01077f

Pardridge, W. M. (2020). Treatment of Alzheimer's Disease and Blood-Brain Barrier Drug Delivery. Pharmaceuticals (Basel) 13. doi:10.3390/ph13110394

Park, J.-S., Shin, J. A., Jung, J.-S., Hyun, J.-W., Van Le, T. K., Kim, D.-H., et al. (2012). Anti-inflammatory Mechanism of Compound K in Activated Microglia and its Neuroprotective Effect on Experimental Stroke in Mice. J. Pharmacol. Exp. Ther. 341, 59-67. doi:10.1124/jpet.111.189035

Park, K., Kim, E., Han, H., Shim, Y., Kwon, J., Ku, B., et al. (2017). Efficacy and Tolerability of Rivastigmine Patch Therapy in Patients with Mild-To-Moderate Alzheimer's Dementia Associated with Minimal and Moderate Ischemic white Matter Hyperintensities: A Multicenter Prospective Open-Label Clinical Trial. PloS one 12, e0182123. doi:10.1371/journal.pone.0182123

Perez Ortiz, J. M., and Swerdlow, R. H. (2019). Mitochondrial Dysfunction in Alzheimer's Disease: Role in Pathogenesis and Novel Therapeutic Opportunities. Br. J. Pharmacol. 176, 3489-3507. doi:10.1111/bph.14585

Piao, X., Zhang, H., Kang, J. P., Yang, D. U., Li, Y., Pang, S., et al. (2020). Advances in Saponin Diversity of Panax Ginseng. Molecules 25. doi:10.3390/ molecules 25153452

Pyo, M.-K., Choi, S.-H., Shin, T.-J., Hwang, S.-H., Lee, B.-H., Kang, J.-Y., et al. (2011). A Simple Method for the Preparation of Crude Gintonin from Ginseng Root, Stem, and Leaf. J. Ginseng Res. 35, 209-218. doi:10.5142/ jgr.2011.35.2.209

Quan, Q., Li, X., Feng, J., Hou, J., Li, M., and Zhang, B. (2020). Ginsenoside Rg1 Reduces $\beta$ amyloid Levels by Inhibiting CDK5induced PPAR $\gamma$ Phosphorylation in a Neuron Model of Alzheimer's Disease. Mol. Med. Rep. 22, 3277-3288. doi:10.3892/mmr.2020.11424

Rahman, M. A., Hwang, H., Nah, S.-Y., and Rhim, H. (2020). Gintonin Stimulates Autophagic Flux in Primary Cortical Astrocytes. J. ginseng Res. 44, 67-78. doi:10.1016/j.jgr.2018.08.004

Rajabian, A., Rameshrad, M., and Hosseinzadeh, H. (2019). Therapeutic Potential of Panax Ginseng and its Constituents, Ginsenosides and Gintonin, in Neurological and Neurodegenerative Disorders: a Patent Review. Expert Opin. Ther. Patents 29, 55-72. doi:10.1080/13543776.2019.1556258

Ren, J., Wei, D., An, H., Zhang, J., and Zhang, Z. (2020). Shenqi Yizhi Granules Protect hippocampus of AD Transgenic Mice by Modulating on Multiple Pathological Processes. J. Ethnopharmacol. 263, 112869. doi:10.1016/j.jep.2020. 112869

Saba, E., Jeon, B. R., Jeong, D. H., Lee, K., Goo, Y. K., Kwak, D., et al. (2015). A Novel Korean Red Ginseng Compound Gintonin Inhibited Inflammation by MAPK and NF-Kb Pathways and Recovered the Levels of Mir-34a and Mir-93 in RAW 264.7 Cells. Evid. Based Complement. Alternat Med. 2015, 624132. doi:10.1155/2015/624132

Schindowski, K., Belarbi, K., and Buée, L. (2008). Neurotrophic Factors in Alzheimer's Disease: Role of Axonal Transport. Genes Brain Behav. 7 (Suppl. 1), 43-56. doi:10.1111/j.1601-183x.2007.00378.x

Seo, Y.-M., Choi, S. J., Park, C. K., Gim, M. C., and Shin, D.-H. (2018). Synergistic Effect of Korean Red Ginseng and Pueraria montana Var. Lobata against 
Trimethyltin-Induced Cognitive Impairment. Food Sci. Biotechnol. 27, 1193-1200. doi:10.1007/s10068-018-0362-9

Shi, R., Zhang, S., Cheng, G., Yang, X., Zhao, N., and Chen, C. (2018). Ginsenoside Rg1 and Acori Graminei Rhizoma Attenuates Neuron Cell Apoptosis by Promoting the Expression of miR-873-5p in Alzheimer's Disease. Neurochem. Res. 43, 1529-1538. doi:10.1007/s11064-018-2567-y

Shi, Z. Y., Zeng, J. Z., and Wong, A. S. T. (2019). Chemical Structures and Pharmacological Profiles of Ginseng Saponins. Molecules 24. doi:10.3390/ molecules 24132443

Shin, S. J., Jeon, S. G., Kim, J. I., Jeong, Y. O., Kim, S., Park, Y. H., et al. (2019). Red Ginseng Attenuates A $\beta$-Induced Mitochondrial Dysfunction and A $\beta$-Mediated Pathology in an Animal Model of Alzheimer's Disease. Int. J. Mol. Sci. 20. doi:10.3390/ijms20123030

Shin, S. J., Nam, Y., Park, Y. H., Kim, M.-J., Lee, E., Jeon, S. G., et al. (2021). Therapeutic Effects of Non-saponin Fraction with Rich Polysaccharide from Korean Red Ginseng on Aging and Alzheimer's Disease. Free Radic. Biol. Med. 164, 233-248. doi:10.1016/j.freeradbiomed.2020.12.454

Shin, S. J., Park, Y. H., Jeon, S. G., Kim, S., Nam, Y., Oh, S. M., et al. (2020). Red Ginseng Inhibits Tau Aggregation and Promotes Tau Dissociation In Vitro. Oxid Med. Cel Longev 2020, 7829842. doi:10.1155/2020/7829842

Sonawane, S., Uversky, V., and Chinnathambi, S. (2021). Baicalein Inhibits HeparinInduced Tau Aggregation by Initializing Non-toxic Tau Oligomer Formation. Cell Commun. signaling : CCS 19, 16. doi:10.1186/s12964-021-00704-3

Sung, P. S., Lin, P. Y., Liu, C. H., Su, H. C., and Tsai, K. J. (2020). Neuroinflammation and Neurogenesis in Alzheimer's Disease and Potential Therapeutic Approaches. Int. J. Mol. Sci. 21. doi:10.3390/ijms21030701

Vaz, M., and Silvestre, S. (2020). Alzheimer's Disease: Recent Treatment Strategies. Eur. J. Pharmacol. 887, 173554. doi:10.1016/j.ejphar.2020.173554

Wang, X.-j., Zhang, A.-h., Kong, L., Yu, J.-b., Gao, H.-l., Liu, Z.-d., et al. (2019). Rapid Discovery of Quality-Markers from Kaixin San Using Chinmedomics Analysis Approach. Phytomedicine 54, 371-381. doi:10.1016/j.phymed.2017. 12.014

Wang, Y., Li, Y., Yang, W., Gao, S., Lin, J., Wang, T., et al. (2018). Ginsenoside Rb1 Inhibit Apoptosis in Rat Model of Alzheimer's Disease Induced by A $\beta 1-40$. Am. J. Transl Res. 10, 796-805.

Xu, T. Z., Shen, X. Y., Sun, L. L., Chen, Y. L., Zhang, B. Q., Huang, D. K., et al. (2019). Ginsenoside Rg1 Protects against $\mathrm{H} 2 \mathrm{O} 2$-induced N-euronal D-amage D-ue to I-nhibition of the NLRP1 I-nflammasome S-ignalling P-athway in H-ippocampal N-eurons I-n vitro. Int. J. Mol. Med. 43, 717-726. doi:10.3892/ ijmm.2018.4005

Yabe, T., Tuchida, H., Kiyohara, H., Takeda, T., and Yamada, H. (2003). Induction of NGF Synthesis in Astrocytes by Onjisaponins of Polygala Tenuifolia, Constituents of Kampo (Japanese Herbal) Medicine, Ninjin-Yoei-To. Phytomedicine 10, 106-114. doi:10.1078/094471103321659799

Yakoot, M., Salem, A., and Helmy, S. (2013). Effect of Memo ${ }^{\circledR}$, a Natural Formula Combination, on Mini-Mental State Examination Scores in Patients with Mild Cognitive Impairment. Cia 8, 975-981. doi:10.2147/cia.s44777

Yan, X., Hu, G., Yan, W., Chen, T., Yang, F., Zhang, X., et al. (2017). Ginsenoside Rd Promotes Non-amyloidogenic Pathway of Amyloid Precursor Protein Processing by Regulating Phosphorylation of Estrogen Receptor Alpha. Life Sci. 168, 16-23. doi:10.1016/j.lfs.2016.11.002
Yang, L., Hao, J., Zhang, J., Xia, W., Dong, X., Hu, X., et al. (2009). Ginsenoside Rg3 Promotes Beta-Amyloid Peptide Degradation by Enhancing Gene Expression of Neprilysin. J. Pharm. Pharmacol. 61, 375-380. doi:10.1211/ jpp/61.03.0013

Yang, Q., Lin, J., Zhang, H., Liu, Y., Kan, M., Xiu, Z., et al. (2019b). Ginsenoside Compound K Regulates Amyloid $\beta$ via the Nrf2/Keap1 Signaling Pathway in Mice with Scopolamine Hydrobromide-Induced Memory Impairments. J. Mol. Neurosci. 67, 62-71. doi:10.1007/s12031-018-1210-3

Yang, Y., Jia, X., Feng, J., Wang, Z., Cao, Y., Liu, J., et al. (2017). Fuzheng Quxie Decoction Ameliorates Learning and Memory Impairment in SAMP8 Mice by Decreasing Tau Hyperphosphorylation. Evid. Based Complement. Alternat Med. 2017, 5934254. doi:10.1155/2017/5934254

Yang, Y., Li, S., Huang, H., Lv, J., Chen, S., Pires Dias, A. C., et al. (2020). Comparison of the Protective Effects of Ginsenosides Rb1 and Rg1 on Improving Cognitive Deficits in SAMP8 Mice Based on Anti-neuroinflammation Mechanism. Front. Pharmacol. 11, 834. doi:10.3389/fphar.2020.00834

Yang, Y., Liang, X., Jin, P., Li, N., Zhang, Q., Yan, W., et al. (2019a). Screening and Determination for Potential Acetylcholinesterase Inhibitory Constituents from Ginseng Stem-Leaf Saponins Using Ultrafiltration (UF)-LC-ESI-MS 2. Phytochem. Anal. 30, 26-33. doi:10.1002/pca.2787

Yankner, B., Dawes, L., Fisher, S., Villa-Komaroff, L., Oster-Granite, M., and Neve, R. (1989). Neurotoxicity of a Fragment of the Amyloid Precursor Associated with Alzheimer's Disease. Science 245, 417-420. doi:10.1126/science.2474201

Zhang, A. H., Yu, J.-B., Sun, H., Kong, L., Wang, X. Q., Zhang, Q.-Y., et al. (2018). Identifying Quality-Markers from Shengmai San Protects against Transgenic Mouse Model of Alzheimer's Disease Using Chinmedomics Approach. Phytomedicine 45, 84-92. doi:10.1016/j.phymed.2018.04.004

Zhang, Y., Yang, X., Wang, S., and Song, S. (2019). Ginsenoside Rg3 Prevents Cognitive Impairment by Improving Mitochondrial Dysfunction in the Rat Model of Alzheimer's Disease. J. Agric. Food Chem. 67, 10048-10058. doi:10. 1021/acs.jafc.9b03793

Zhao, B.-S., Liu, Y., Gao, X.-Y., Zhai, H.-Q., Guo, J.-Y., and Wang, X.-Y. (2014). Effects of Ginsenoside Rg1 on the Expression of Toll-like Receptor 3, 4 and Their Signalling Transduction Factors in the NG108-15 Murine Neuroglial Cell Line. Molecules 19, 16925-16936. doi:10.3390/molecules191016925

Zhao, J., Lu, S., Yu, H., Duan, S., and Zhao, J. (2018). Baicalin and Ginsenoside Rb1 Promote the Proliferation and Differentiation of Neural Stem Cells in Alzheimer's Disease Model Rats. Brain Res. 1678, 187-194. doi:10.1016/j. brainres.2017.10.003

Conflict of Interest: The authors declare that the research was conducted in the absence of any commercial or financial relationships that could be construed as a potential conflict of interest.

Copyright $\odot 2021$ Li, Huang, Chen, Qi, Liu, Chen, Zhao, Wang and Li. This is an open-access article distributed under the terms of the Creative Commons Attribution License (CC BY). The use, distribution or reproduction in other forums is permitted, provided the original author $(s)$ and the copyright owner(s) are credited and that the original publication in this journal is cited, in accordance with accepted academic practice. No use, distribution or reproduction is permitted which does not comply with these terms. 